\title{
INTERPRETATION AND ENACTMENT: THE YERUSHALMI Story of Elisha ben Abuyah and the Book \\ OF RUTH \\ Devora Steinmetz
}

\author{
Dedicated to the memory of my mother-in-law, Martha C. Silber
}

\begin{abstract}
The aggadah about Elisha ben Abuyah and R. Meir in $Y$. Hagigah 2:1 (77b-c) includes a striking interpretation and enactment of a verse from the book of Ruth. In the climactic scene, $R$. Meir spreads his garment over his master's burning grave, performing the deed that Ruth requests of Boaz on the threshing floor, and offers a bold interpretation of Ruth 3:13, Boaz's reply to that request. The combined interpretation and enactment of this dramatic scene in the Ruth story at the climactic moment of the aggadah suggests that one might look for a more extensive engagement of the rabbinic narrative with the biblical story. This article explores ways in which the aggadah might be read in relation to the book of Ruth and argues that such a reading highlights core themes of the aggadah and helps disclose the theological and moral stance of this rabbinic narrative.
\end{abstract}

Elisha ben Abuyah's name occurs only seldom in rabbinic texts, but the stories about him in both Bavli and Yerushalmi Hagigah have captured the imagination of many students of rabbinic literature as well as people with little or no familiarity with rabbinic texts. ${ }^{1}$ Also known as Aher_- "the other"-Elisha ben Abuyah is portrayed as having been in the center of rabbinic life and as having permanently abandoned that world. Rabbinic texts about Elisha and, in particular, about his relationship with his student, Rabbi Meir, allow a glimpse into how those who remain within that world imagine relating to one of their own who has left.

A well-known story about Elisha ben Abuyah's encounter with R. Meir appears, with significant variations, in both the Bavli and Yerushalmi (B. Hagigah 15a-b; Y. Hagigah 2:1 [77b-c]). ${ }^{2}$ The focus of this article is a striking

1. Milton Steinberg's As a Driven Leaf (Springfield: Behrman House, 1939) has contributed significantly to popular familiarity with Elisha ben Abuyah.

2. Several extended treatments of these narratives and of the larger passages about Elisha in which they are embedded have been published in recent years. For detailed literary analyses of these narratives, see Jeffrey Rubenstein, "Elisha ben Abuya: Torah and the Sinful Sage," The Journal of Jewish Thought and Philosophy 7 (1998): 139-225 (and the chapter of that name in Talmudic Stories: Narrative Art, Composition, and Culture [Baltimore: Johns Hopkins University Press, 1999], 64-104; the references below are to Rubenstein's article); Alon Goshen-Gottstein, The Sinner and the Amnesiac: The Rabbinic Invention of Elisha ben Abuya and Eleazar ben Arach (Stanford: 


\section{Devora Steinmetz}

feature of the Yerushalmi version of this story: at a climactic moment in this narrative, $R$. Meir offers a midrashic interpretation of a verse from the book of Ruth and simultaneously enacts the promise that is affirmed in that verse. He spreads his cloak over Elisha's burning grave, corresponding to Ruth's request to Boaz to spread his cloak over her (Ruth 3:9), and he challenges God to redeem his master, asserting, through an exegesis of the verse in which Boaz responds to Ruth's request (Ruth 3:13), that if God refuses, he will do so himself. His citation and explication of the latter verse explain the meaning of his action - spreading his cloak over Elisha's grave enacts the promise to redeem that is articulated in R. Meir's exegesis of the verse from Ruth.

Below is the text of the Yerushalmi story of Elisha ben Abuyah and R. Meir in the original and in translation. ${ }^{3}$ The biblical verses cited in the narrative appear in bold, and a different bold font is used to highlight the verse from Ruth that R. Meir declaims and interprets at the climax of the story.

ר"מ הוה יתיב דרש בבית מדרשא דטיבריה. עבר אלישע רביה רכיב ערל על סוסייא ביום דיבריבריה שובתא.

אתון ואמרון ליה הא רביה לכיבר לבר. פסק ליה מן דרשה ונפק לגביה.

א"ל מה הויתה דרש יומא דין? א"ל ויי' ברך את אחרית [איוב מראשיתו] וגו' (איוב מב:יב).

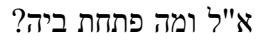
א"ל ויוסף יי' את כל אשר לאיוב למשנה (איוב מב:י)-שכפל לו את כל ממונו. אמר ווי דמובדין ולא משכחין!

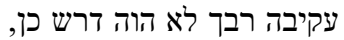
אלא ויי' ברך את אחרית איוב מראשיתו -בזכות מצות ומעשים טובים שהיה בידו מראשיתו.

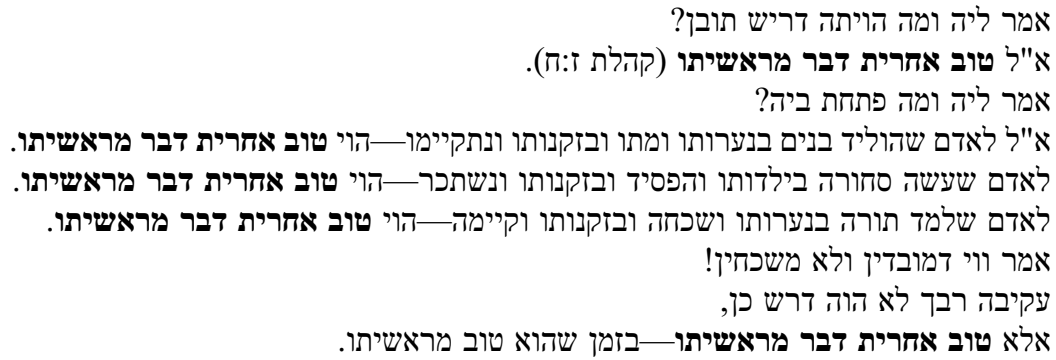

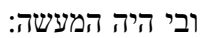

Stanford University Press, 2000); Nurit Be'eri, Yaza'le-tarbut ra 'ah: Elisha ben Avuyah - “Aher” (Tel Aviv: Yediot Ahronot, 2007). See also Yehuda Liebes, Het'o shel Elisha (Jerusalem: Magnes, 1990).

3. The text is downloaded from the Bar-Ilan Responsa database. The translation is my own, with reference to the translations of Rubenstein, "Elisha," and Goshen-Gottstein, Sinner. Parallels and partial parallels appear in Ruth Rabbah 6:4 (ed. Lerner, pp. 164-74), Kohelet Rabbah 7:8, and Midrash Mishle 6:26 (ed. Visotzky, p. 50). 
אבויה אבא מגדולי ירושלם היה. ביום שבא למוהליני קרא לכל גדולי ירושלם והושיבן בבית ירוית אחד ולר' אליעז' ולר' יהושע בבית אחר. מן דאכלון ושתון שרון מטפחין ומרקדין. א"ר ליעזר לר' יהושע עד דאינון עסיקין בדידון ומין נעסון ועסוק אנן בדידן. וישבו ונתעסקו בדברי תורה מן התורה לנביאיאים ומידים ומן הנביאי' לכתובים

וירדה אש מן השמים והקיפה אותם.

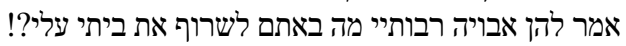

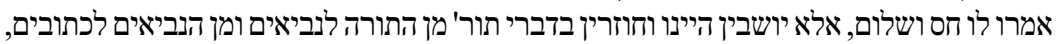

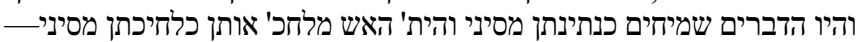

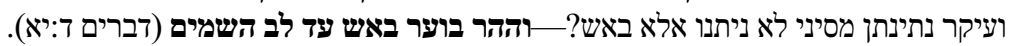

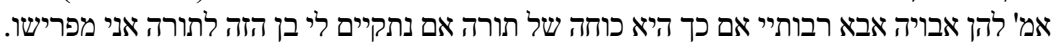
לפי שלא היתה כוונתו לשם שמים לפיכך לא נתקיימו באותו האיש.

\section{אמר ליה ומה הויתה דרש תובן? א"ל לא יערכנה זהב וזכוכית (איוב כח:יז).}

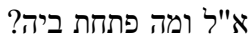
א"ל דברי תורה קשין לקנות ככלי זהב ונוחין לאבד ככלי זכוכית,

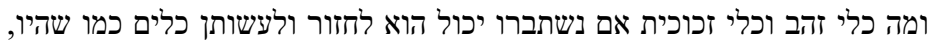
אף תלמיד חכם ששכח תלמודו יכול הוא לחזור וללמדו כתחילה.

א"ל דייך מאיר עד כאן תחום שבת. א"ל מן הן את ידע? דיר מאיר א"ל מן טלפי דסוסיי דהוינא מני והולך אלפיים אמה.

א"ל וכל הדא חכמתא אית בך ולית ולית את חזר בך?

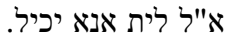
א"ל למה? ל אית איל א"ל שפעם אחת הייתי עובר לפני בית קודש הקדשי' רכוב על סוסי בי"ה שחל להיות בשבית ירות

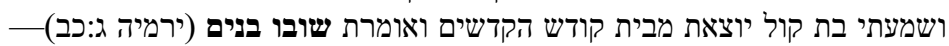
חוץ מאלישע בן אבויה שידע כחי ומרד בי.

וכל דא מן הן אתת ליה?

אלא פעם אחת היה יושב ושונה בבקעת גיניסר,

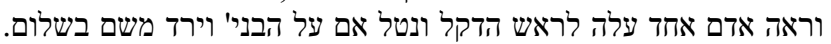

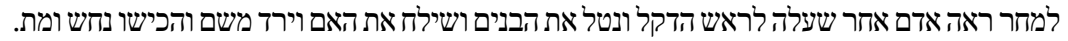
אמר כתיב שלח תשלח את האם ואת הבנים תקח לך למען ייטב לך והארכת ימים (דברים כב:ז)-

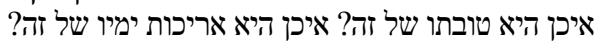

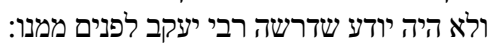

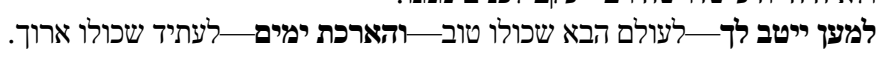

ויש אומ' ע"י שראה לשונו של רבי יהודה הנחתום נתון בפי הכלב שותת דם.

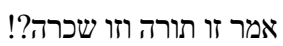
זהו הלשון שהיה מוציא דברי תורה כתיקנן? זה הוא הלשון שהיה יגיע בתורה כלימיו? זו תורה וזו שכרה?! דומה שאין מתן שכר ואין תחיית המתים.

ויש אומרים אמו כשהיתה מעוברת בו היתה עוברת על בתי עבודה זרה והריחה מאותו המין, והיה אותו הריח מפעפע בגופה כאירסה של חכינה. 


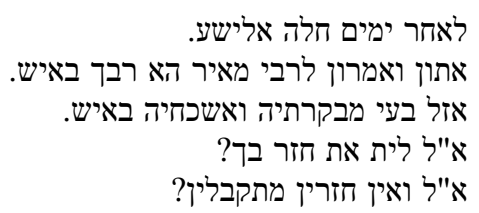

א"ל ולא כן כתיב תשב אנוש עד דכא (תהלים צ:ג)?-עד דילד דיכדוכה של נפש מקבלין.

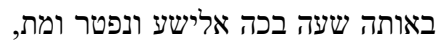
והיה רבי מאיר שמח בלבו ואומר דומה שמתוך תשובה נפטר רבי.

מן דקברוניה ירדה האש מן השמים ושרפה את קברו.

אתון ואמרון לר"מ הא קבריה דרבך אייה הפיהד.

נפק בעי מבקרתיה ואשכחיה אייקד.

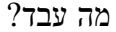

נסב גולתיה ופרסיה עלוי.

אמ' ליני הלילה וגו'--ליני בעולם הזה שדומה ללילה

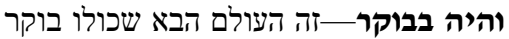

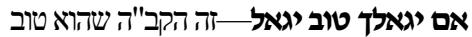

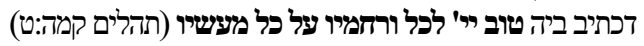

ואם לא יחפוץ לגאלך וגאלתיך אנכי חי "י' (רות ג:ג).

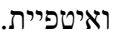

אמרון לר"מ אין אמרין לך בההוא עלמא למאן את בעי למבקר' לאבוך או לרבך?

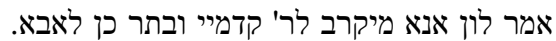

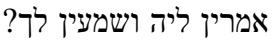

אמ' לון ולא כן תנינן מצילין תיק הספר עם הספר תיק תפילין עם התפילין (משנה שבת טז:א)? מצילין לאלישע אחר בזכות תורתו.

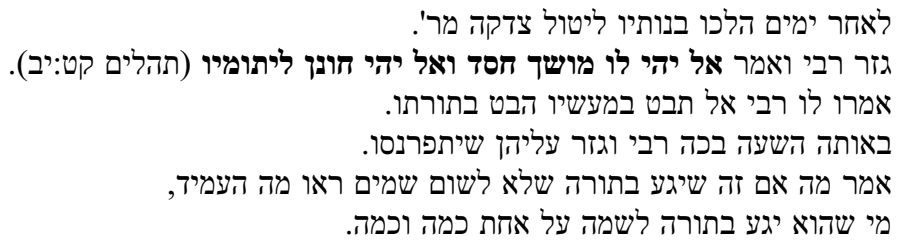

R. Meir was sitting expounding [darash] in the beit midrash of Tiberias.

His master Elisha passed by riding on a horse on the Sabbath day.

They came and said to him: Behold, your master is outside!

He stopped his teaching [derashah] and went out to him.

He said to him: What were you expounding today?

He said to him: "And the Lord blessed the end of Job more than [me-] his beginning" (Job 42:12).

He said to him: And how did you begin it?

He said to him: "And the Lord increased all that Job had twofold" (Job 42:10). He said: Woe for what is lost and cannot be found! 
Your master Akiva did not expound thus, rather: "And the Lord blessed the end of Job more than his beginning"in the merit of the mitzvot and good deeds that he possessed from [me-] his beginning.

He said to him: And what else were you expounding?

He said to him: "The end of a thing is better [tov] than [me-] its beginning" (Ecclesiastes 7:8).

He said to him: And how did you begin it?

He said to him: [It is like] a person who begat children in his youth and they died, and in his old age and they survived [ve-nitkaymu] -

this is "The end of a thing is better than its beginning";

a person who did trade when he was young and lost it, and in his old age and profitedthis is "The end of a thing is better than its beginning";

a person who learned Torah in his youth and forgot it, and in his old age and maintained it [ve-kiymah]

this is "The end of a thing is better than its beginning."

He said: Woe for what is lost and cannot be found!

Your master Akiva did not expound thus,

rather: "The end of a thing is better than its beginning"-when it is good from [me-] its beginning.

And this incident happened to me:

Abuyah, my father, was one of the great men of Jerusalem.

On the day that he was to circumcise me, he called all of the great men of Jerusalem to one house and R. Eliezer and R. Yehoshua in another house.

When they had eaten and drunk, they began clapping and dancing.

R. Eliezer said to R. Yehoshua: While they are occupied with theirs, let us occupy ourselves with ours.

And they sat and occupied themselves with words of Torah, from the Torah to the Prophets, and from the Prophets to the Writings.

And fire came down from heaven and surrounded them.

Abuyah said to them: My masters, have you come to burn my house upon me?!

They said to him: God forbid, rather we were sitting and going over [ve-hozrin] words of Torah, from the Torah to the Prophets, and from the Prophets to the Writings,

And the words were joyful as when they were given at Sinai, and fire was lapping at them as it lapped at them at Sinai-

Were they not originally given at Sinai in fire? - "And the mountain blazed with fire to the heart of the heavens" (Deuteronomy 4:11).

Abuyah, my father, said to them: My masters, if thus is the power [kohah] of Torah, if this child survives [nitkayem], I dedicate him to Torah.

Because his intention was not for the sake of heaven, therefore they were not maintained $[$ nitkaymu $]$ in that man. 


\section{Devora Steinmetz}

He said to him: And what else were you expounding?

He said to him: "Gold and glass cannot match its value" (Job 28:17).

He said to him: And how did you begin it?

He said to him: Words of Torah are as difficult to acquire as gold vessels and as easy to lose like glass vessels. And just as gold vessels and glass vessels, if they have broken, one can return [lahzor] and make them into vessels as they were, so a sage who forgot his learning can return [lahzor] and learn it as at the beginning.

He said to him: Enough, Meir! Until here is the Sabbath boundary.

He said to him: How do you know?

He said to him: From the steps of my horse, which I was counting, and he has walked two thousand cubits.

He said to him: And you have all this wisdom and you will not repent/return [hazar]?!

He said to him: I am not able to.

He said to him: Why?

He said to him: Because one time I was passing before the house of the holy of holies riding on my horse on Yom Kippur that fell on Shabbat,

And I heard a heavenly voice coming out of the house of the holy of holies and saying: "Return children" (Jeremiah 3:22) -

except [huz mi-] Elisha ben Abuyah who knew my power [kohi] and rebelled against me.

And all this, how did it come upon him?

Rather one time he was sitting and studying in the Valley of Gennesaret, and he saw a person go up to the top of a palm tree and take a mother [bird] with her children, and he came down from there in peace.

The next day, he saw a person go up to the top of a palm tree and take the children and send away the mother, and he came down from there, and a snake bit him, and he died.

He said: It is written "You shall surely send away the mother and the children you shall take for yourself, in order that it be good [yitav] for you and that you lengthen your days" (Deuteronomy 22:7) -

Where is this one's good [tovato]? Where is this one's length of days?

And he did not know that R. Yaakov had already explicated [derashah] it:

"in order that it be good [yitav] for you"-in the world to come, which is all [she-kulo] good [tov]-

"and that you lengthen your days"-in the future which is all [she-kulo] long.

And some say: Because he saw the tongue of R. Yehudah Hanahtom in the mouth of a dog dripping blood. He said: This is Torah and this is its reward?! This is the tongue that was bringing forth words of Torah as they are fit to be? This is the tongue that was laboring in Torah all of its days? This is Torah and this is its reward?! 
It seems that there is no giving of reward and there is no resurrection of the dead.

And some say: His mother, when she was pregnant with him, would pass by houses of idolatry and she smelled of that thing, and that smell penetrated her body like the venom of a snake.

A while later [le-'ahar yamim], Elisha became ill.

They came and said to R. Meir: Behold, your master is ill. He went seeking to visit him [ba'e mevakarte] and found him ill. He said to him: Will you not repent/return [hazar]? He said to him: And if one repents/returns [hazrin], is he accepted? He said to him: Is it not written "You cause the human being to return to dust [daka']" (Psalms 90:3)? - they accept until the crushing [dikhdukhah] of life. At that moment [be-'otah sha 'ah], Elisha cried and he departed and died.

And R. Meir was glad in his heart, and he said: It seems that master departed repentant [mitokh teshuvah].

When they buried him, fire came down from the heavens and burned his grave. They came and said to R. Meir: Behold, the grave of your master is burning. He went out seeking to visit him [ba'e mevakarte] and found it burning. What did he do?

He took his cloak and spread it over him.

He said: "Stay the night" — stay in this world that is similar to night, "and it will be in the morning" - this is the world to come that is entirely [she-kulo] morning,

"if he will redeem you, good [tov], let him redeem you"- this is the blessed Holy One who is good,

as it is written: "The Lord is good [tov] to all $[l a-k o l]$, and his mercy is upon all of his creations" (Psalms 145:9),

"and if he will not want to redeem you, then I will redeem you, as the Lord lives" (Ruth 3:13).

And it was extinguished.

They said to R. Meir: If they say to you in that world "Whom do you seek to visit-your father or your master?"

He said to them: I will visit my master first and after that my father.

They said to him: And will they listen to you?

He said to them: Have we not learned "One saves the covering of the scroll together with the scrolls, the covering of the tefillin together with the tefillin" (M. Shabbat 16:1)?-

One saves Elisha-Aher in the merit of his Torah.

A while later [le-'ahar yamim], his daughters went to receive charity from Rabbi. Rabbi decreed saying "Let there not be one to extend hesed to him, and let there not be one who is gracious to his orphans" (Psalms 109:12). 


\section{Devora Steinmetz}

They said to him: Rabbi, do not look at his deeds; look at his Torah.

At that moment [be-'otah ha-sha'ah], Rabbi cried and decreed that they be supported.

He said: If this one who labored in Torah not for the sake of heaven, see what he raised up, one who labored in Torah for its own sake, how much more so!

\section{Citation and Explication of Biblical Verses}

This aggadah cites and explicates quite a number of verses; in fact, I will argue below that how a person interprets Scripture is a core theme of the aggadah. But the derashah on the Ruth verse is unique in several ways. First, it goes beyond the verbal articulation of an interpretation of the verse. Here, the phrase-by-phrase citation and explication of the verse accompany an action that R. Meir performs, and they serve as the narration of the meaning of that action-or perhaps one might say that, in taking the action that he takes, R. Meir makes real his understanding of the verse from Ruth.

Second, most of the other verses cited and explicated in this aggadah are either the focus of an interpretive discussion or the prooftext or countertext for an argument that someone is making. In the first part of the story, R. Meir cites a series of biblical verses in response to Elisha's asking what he had been explicating in the beit midrash that day. These verses then serve as the focus of contesting interpretations offered by R. Meir and Elisha. Other verses are quoted by characters in the aggadah, often but not always introduced by a citation formula such as "is it not written," in order to prove a point or to raise a problem. For example, R. Meir quotes Psalms 90:3 and offers an interpretation of this verse in order to prove to Elisha that one can always repent, and Elisha quotes Deuteronomy 22:7 in order to point out the falsehood of the promise of this verse in the face of the reality he has witnessed. The case of the Ruth verse is different. Here, R. Meir does not quote the verse in order to prove a point. Rather, he recites the verse as the speaker of the verse. The words that he speaks are in the first person and are a direct address - in the book of Ruth, they are spoken by Boaz to Ruth. Thus, declaiming this verse can be seen as positioning R. Meir within the passage that he cites. In a sense, as the first-person speaker of words spoken in the book of Ruth, he not only recalls and imitates a scene from that narrative but enacts that scene. ${ }^{4}$

Finally, the verse that $\mathrm{R}$. Meir cites is from the climactic scene in the book of Ruth, in which Ruth visits Boaz on the threshing floor and Boaz makes a promise to her. Similarly, R. Meir's exegesis of this verse and his enactment of its promise serve as the climax of the aggadah. This, along with the fact that R. Meir appears to

4. One other verse in the aggadah appears neither as the subject of an interpretive discussion nor as a prooftext for an argument: Jeremiah 3:22, which Elisha reports hearing from a bat kol. Here, as in the case of the Ruth verse, the speaker in the aggadah is speaking the words of the biblical text, rather than merely citing them. But, unlike in the case of the Ruth verse, here Elisha hears a divine voice speak God's words, or perhaps hears God's ongoing call to return, as part of the message that he receives. In the present case, it is a human figure, R. Meir, who speaks the words spoken at a particular narrative moment by a different human speaker, Boaz, in the book of Ruth. 
be entering into the story of Ruth as the speaker of the words of Boaz, suggests that one might take a metonymic view of this scene - that we might look beyond this climactic scene in which R. Meir and Elisha are conflated with Boaz and Ruth and imagine the entire narrative of the aggadah as, in some way, echoing or perhaps enacting the narrative of the book of Ruth.

Of course, rabbinic texts often cite biblical verses. The tendency in academic study of this phenomenon has been to assume that rabbinic texts atomize the biblical text they quote, focusing on the word or phrase or verse that is being cited without regard to the larger context of those words. ${ }^{5}$ Some scholars, though, have argued that often this is not the case, that midrashic exegesis of a word or phrase should be examined in relation to the broader biblical passage in which that word or phrase appears, or that the citation or echo of a biblical verse in an aggadah invites the reader to consider the relationship of the aggadic story to the biblical narrative or passage in which the verse occurs. ${ }^{6}$ While in general I am open to the possibility that a rabbinic text might be engaging a broad contextual reading of the biblical verse that it cites, I think that the distinctive features of the citation of the Ruth verse in our aggadah suggest that such an engagement is particularly likely to be found in this text.

Imagining that R. Meir's speaking, interpreting, and enacting Boaz's critical words at the climactic moment in the aggadah evokes both the biblical scene and the larger narrative in which these words are spoken, this article will explore echoes of the book of Ruth in the aggadah. ${ }^{7}$ Indeed, I think it likely that this aggadah is actually shaped, in part, in relation to key elements of the biblical narrative. But, whatever claims one might or might not want to make about the composition of this aggadah, reading the aggadah in conversation with the book of

5. The classic statement of this approach is James L. Kugel, "Two Introductions to Midrash," reprinted in Midrash and Literature, ed. Geoffrey H. Hartman and Sanford Budick (New Haven: Yale University Press, 1986), 77-103 (originally published in Prooftexts 3 [1983]: 131-55).

6. See Devora Steinmetz, "Beyond the Verse: Midrash Aggadah as Interpretation of Biblical Narrative," AJS Review 30, no. 2 (2006): 325-45. For an example of the argument that an aggadah might be partially shaped in relation to a biblical narrative, see Inbar Raveh, "'Avi,'avi: Ha-hebet ha-ben-tekstu'ali be-sugyat ha-biyografiyah shel hakhamim," Ha-hinukh u-svivo 33 (2007): 333-42. (Raveh argues, further, that the broader aggadic portrait of a rabbinic figure may be shaped in relation to a biblical figure.) Note that the case that Raveh examines is similar to our case, in that a character in the aggadah speaks the words of a biblical character.

Richard B. Hays, in Echoes of Scripture in the Letters of Paul (New Haven: Yale University Press, 1989), develops a similar argument regarding scriptural echoes in Paul's writings. See especially chapter 1, where he discusses his approach in terms that he calls "allusive echo" or "metalepsis": "Allusive echo functions to suggest to the reader that text B should be understood in light of a broad interplay with text A, encompassing aspects of A beyond those explicitly echoed... . Metalepsis ... places the reader within a field of whispered or unstated correspondences" (20).

7. For the notion that this kind of reading is an imaginative act, see Hays, Echoes of Scripture, 23: "At the explicit literal level of the discourse, Paul simply borrows a phrase from Job to express confidence amidst trying circumstances. But when the source of the phrase is read in counterpoint with the new setting into which it has been transposed, a range of resonant harmonics becomes audible... . The trope [of metalepsis] invites the reader to participate in an imaginative act necessary to comprehend the portrayal of Paul's condition offered here." 


\section{Devora Steinmetz}

Ruth highlights core themes and helps disclose the theological and moral stance of this rabbinic narrative. ${ }^{8}$

A few comments about the text and about my formatting of the text are in order. The boundaries of the passage, as well as the question as to whether every section of the passage should be seen as part of the narrative, are subject to debate and have been discussed extensively in recent scholarship. For the purposes of this study, I have omitted the passage that immediately precedes this section in the Yerushalmi. That passage takes the form of a sustained interpretation of the tannaitic tradition about the four who entered the pardes and does not seem to be integrated structurally or thematically with the narrative about Elisha ben Abuyah and R. Meir. ${ }^{9}$ I have included, however, all of the segments that appear within the boundaries of the story about Elisha and R. Meir, as well as the two post- and perhaps anticlimactic final segments of the narrative.

The sections that I have indented, while they appear to interrupt the flow of the narrative, ${ }^{10}$ share some key elements with other parts of the passage - perhaps most notably, the second of these includes a derashah on a verse about goodness (yitav/tov) and about a future time that is entirely (she-kulo) different from the present time, elements that appear in the climactic scene of the aggadah-and so I treat them as an integral part of the narrative. I have indented them to highlight that they represent flashbacks in time; they are offered at key points in the narrative as background explanations of significant elements of the narrative, but the events they relate are not part of the story that unfolds in chronologically consecutive episodes. It should be noted that narrative interruptions like these can serve important literary functions. For example, the section in which the narrator steps out of the story to ask and offer three answers about how Elisha came to this point serves as a kind of intermission between the two acts of the narrative (to use the language of

8. It is beyond the scope of this article to enter into the complex field of theories of intertextuality. Hays's Echoes of Scripture spurred a significant debate about this issue in New Testament studies. For a useful summary of some of the key issues, see David A. Shaw, "Converted Imaginations? The Reception of Richard Hays's Intertextual Method," Currents in Biblical Research 11, no. 2 (2013): 234-45. Shaw reviews Hays's criteria for detection of echoes and critical responses to these criteria, as well as proposals for clarifying and distinguishing between terms such as allusion, echo, and quotation. See also Benjamin D. Sommer, "Allusion and Intertextuality in the Hebrew Bible: A Response to Lyle Eslinger," Vetus Testamentum 46, no. 4 (1996): 479-89, for a discussion of how evidence for identifying an allusion might be weighed and for references to scholarship on this important issue, as well as for a succinct articulation of the distinction between allusion and intertextuality. Another significant issue in the discussion about intertextuality is where one sees the intertextual event as occurring, especially whether one sees it as occurring in the writing of the text or in the reading of it; see Hays's brief summary of the possibilities in Echoes, 27, and see the responses to his approach as well as his response to his critics in Paul and the Scriptures of Israel, ed. Craig A. Evans and James A. Sanders, JSNT Supplement Series 83 (Sheffield: JSOT Press, 1993).

9. Rubenstein, "Elisha," 151-55; Goshen-Gottstein, Sinner, 167. Rubenstein, 170, also notes that the portrait of Elisha in this passage seems inconsistent with that in the story that follows, and that this passage does not appear in the parallels in Ruth Rabbah and Kohelet Rabbah.

10. Though to different degrees: the story about Elisha's father is told by Elisha himself as part of his conversation with R. Meir, and thus is presented as part of the story, while the three explanations of what brought Elisha to this state are introduced by the narrator as background to the story. 
drama). It closes the curtain on the scene of R. Meir and Elisha walking/riding side by side on Shabbat and transitions the audience to a much later time when they will meet R. Meir visiting Elisha on his deathbed. ${ }^{11}$ In addition, it enables the action to pause, and the first act to come to a close, at the dramatic moment when Elisha tells R. Meir about the heavenly voice that he heard that excludes him from return. ${ }^{12}$ The first flashback, the story that Elisha tells about his father, serves to slow down the narrative before the critical moment when R. Meir will offer a derashah that will challenge Elisha to return and when Elisha will disclose why he believes that he cannot. In addition, it makes it absolutely clear that Elisha sees the contest of derashot as deeply implicating his own life, alerting the reader to pay close attention to the next derashah and its implications for Elisha.

The final two sections also share key elements with other parts of the passage. For example, the first begins with "they said" ('amrun), an anonymous address to R. Meir, echoing the three prior occurrences of "they came and said" ('atun ve-'amrun), and continues the flow of words that share the root letters $q u f$, bet, and resh, prominent in the immediately preceding segments. ${ }^{13}$ And the last section is linked to the rest of the story as a chronologically later episode introduced by the words "a while later" (le-'ahar yamim), like the earlier episode describing the encounter at Elisha's deathbed. Additionally, the expression "not for the sake of heaven" (she-lo' le-shem shamayim) ${ }^{14}$ the contrast between Torah and deeds (ma 'asim), the words "at that moment" (be-'otah sha 'ah) introducing someone's crying, ${ }^{15}$ and the phrase "labored in Torah" (yaga' ba-torah) echo previous sections of the narrative. It should be noted, as well, that the parallels in Ruth Rabbah and Kohelet Rabbah include all of the sections brought here, and so the passage appears to have been recognized by the editors of these works as a single and self-contained literary unit. ${ }^{16}$

The formatting I used is designed to break up the narrative into subunits and to highlight certain features of the narrative. In addition to indicating all biblical

11. Rubenstein, "Elisha," 163 , notes that this interlude "gives the feeling that some time has passed."

12. For a similar device in the story about the oven of Akhnai (B. Bava Mezi‘a 59a-b), see Devora Steinmetz, "Agada Unbound: Inter-Agadic Characterization of Sages in the Bavli and Implications for Reading Agada," in Creation and Composition: The Contribution of the Bavli Redactors (Stammaim) to the Aggada, ed. Peter Schaefer and Jeffrey Rubenstein (Tübingen, Mohr Siebeck, 2005), 293-337. In that aggadah, too, the interlude both functions as a transition between the two acts of the narrative and serves to pause the story at the dramatic moment when R. Yehoshua rejects the heavenly voice by declaring lo' ba-shamayim hi'. It is interesting that in both narratives the first act ends with a heavenly voice, though in the oven of Akhnai story the voice is rejected, while here Elisha accepts the voice that he has heard as determinative.

13. Rubenstein, "Elisha," 150; Be'eri, Yaza', 74. Be'eri also points out that the mishnah cited refers to saving something from fire, another connection to the preceding scene; see also GoshenGottstein, Sinner, 174.

14. Be'eri, Yaza', 86.

15. Rubenstein, "Elisha," 151.

16. See Rubenstein, "Elisha," 170 n. 61. 


\section{Devora Steinmetz}

citations in bold, I underlined the tannaitic teaching that R. Meir cites in relation to Elisha. The paragraph divisions reflect structural features of the narrative, such as the three occurrences of "what were you expounding" (u-mah havitah darash) and of "they came and said" ('atun ve-'amrun) and the three explanations of the cause of Elisha's rebellion. ${ }^{17}$

\section{AcCompaniment And Return}

Turning now to look at the aggadah in relation to the book of Ruth, the first thing one might notice is the similarity between the first scene of the aggadah and the greater part of the first chapter of Ruth. The aggadah begins as R. Meir leaves the beit midrash upon hearing that Elisha is outside, and the rest of the first part of the narrative takes the form of a conversation between the two men as they walk/ride together in the space between the beit midrash and the Sabbath boundary. The first chapter of Ruth, too, follows Naomi and her daughters-in-law as they travel between two places, Moab and Judah, and reports on the conversations that Naomi has with her daughters-in-law on the way. In each story, the characters are able to be together in this space between the two zones, but a moment comes when the accompanying individual either will or will not be able to step across the boundary and continue to accompany his or her fellow traveler.

In the book of Ruth, Moab is the homeland of Naomi's daughters-in-law; Judah is Naomi's place, a place Naomi left behind but to which she now feels compelled to return. The women can walk together between these two places, but the time comes when the daughters-in-law must decide whether they can continue to accompany Naomi to her place or whether they will return to their own place. Naomi's initially indistinct pair of daughters-in-law now splits into two differentiated figures: Orpah heeds her mother-in-law's urging to return to her own place, while Ruth refuses and insists instead on staying with her mother-in-law and crossing over into Naomi's homeland. In the aggadah, R. Meir leaves his place, the beit midrash, to accompany Elisha, and the two can remain together for a while. But R. Meir, much as he seeks to be with his teacher, cannot cross the Sabbath boundary, and at this point he must leave his teacher behind. The first part of the story ends as Elisha reminds R. Meir that he cannot cross the boundary into the place where Elisha is bound and as Elisha explains why he himself cannot return to his former place. ${ }^{18}$

17. There is, however, a certain arbitrariness in my paragraph divisions. For example, the final paragraph in the first part of the narrative ("He said to him: Enough, Meir!"-'amar lei dayakh Meir) could well be placed as part of the preceding paragraph, as it represents Elisha's response to R. Meir's derashah. I separated these paragraphs to highlight the shift from a focus on derashot to an explicit conversation about R. Meir's and Elisha's respective need to or inability to return and, more practically, in order to break up the text into smaller segments.

18. The juxtaposition of the two men's inability to cross over into each other's place is highlighted in the Ruth Rabbah parallel: Elisha tells R. Meir "Return!" (hazor lekha), while R. Meir asks Elisha "And will you not return?!" (ve-let 'at hazar bekha). Of course, R. Meir does not mean "return" in only the spatial sense. 
Three critical themes are interwoven in each of the opening scenes. The first is the theme of accompaniment. In both stories, the younger characters remarkably leave the place where they belong in order to accompany the older figures. Orpah and Ruth, childless widows of the sons of an elderly widow with no remaining children, belong with their families in their homeland, as Naomi eloquently reminds them, but they leave to accompany their mother-in-law on her journey. R. Meir stunningly stops in the middle of teaching, of delivering a public derashah on Shabbat, ${ }^{19}$ and leaves the beit midrash in order to be with his teacher. Ruth finds herself able to continue to accompany her older companion, in fact to swear that she will remain with Naomi forever, while R. Meir is forced to stop at the Sabbath boundary. Nevertheless the greater part of the first act of the aggadah has R. Meir walking with his master and seeking a way to bring him back to a place that they share. ${ }^{20}$

The theme of accompaniment continues throughout the second act of the aggadah. In each of the first two scenes of this act, as in the opening scene of the narrative, "they" come and tell R. Meir about Elisha's state, and R. Meir goes to visit his master, much as he left the beit midrash to be with Elisha in the opening scene. But once again R. Meir is forced to part from his master, this time because Elisha has crossed the boundary between life and death. Although R. Meir visits Elisha's grave, he cannot join his master. The climactic scene in which he enacts and expounds the verse from Ruth underscores this separation and also makes it clear that $\mathrm{R}$. Meir hopes one day to rejoin his master, in death. The following section of the narrative articulates this intention explicitly, as R. Meir tells "them" of his plan to visit his master "in that other world." ${ }^{21}$ It is

19. Though Yonah Fraenkel, Darkhe ha-'aggadah ve-ha-midrash (Herzliya: Yad la-Talmud, 1991), 1:2, suggests that R. Meir is expounding Scripture in the presence of teachers and colleagues, rather than delivering a lecture to the general public.

20. In fact, as Be'eri points out (Yaza', 58), the reader does not know that Elisha has continued on his way and that R. Meir has been following him until Elisha stops R. Meir at the Shabbat boundary. (In the Bavli, in contrast, the scene in which Elisha is riding his horse on Shabbat begins by informing the reader that R. Meir is walking after him.) The reader might well have imagined that Elisha has stopped his horse, or even that he has dismounted to talk with R. Meir, but it suddenly becomes clear that Elisha has been inexorably bound on his way away from the vicinity of the beit midrash and toward the zone outside the Shabbat boundary. The delayed and sudden way in which the narrative lets the reader know that Elisha has continued on his way emphasizes that this is a scene of accompaniment $-\mathrm{R}$. Meir is accompanying Elisha on his way - rather than a scene of the two men walking together.

21. Our text of the Yerushalmi has different verbs in the question and in R. Meir's response to the question; the first reads lemevakre (to visit) and the second mikrav. It could be that one or the other of these is an error and that both should be either the verb $b-k-r$ or the word $k-r-v$. Be'eri, Yaza', 67-68, prefers the second alternative, and understands the word to connote saving from perdition. While $k-r-v$ certainly can have the connotation of bringing near from a state of having been cut off (see references in Be'eri, and see Devora Steinmetz, "Distancing and Bringing Near: A New Look at Mishna Tractates Eduyot and Avot," HUCA 73 [2002]: 49-96 n. 34, and see n. 103 in relation to the aggadah about Elisha ben Abuyah in the Bavli), it is hard to see how this would make sense in relation to R. Meir's father. Others understand $k-r-v$ here as connoting coming close to (Rubenstein, "Elisha," 146, translates "approach"; see his brief discussion of the reading at 166 n. 49 and see Goshen-Gottstein, 


\section{Devora Steinmetz}

striking, in this context, that Ruth's vow to remain with her mother-in-law culminates with the assertion that she will accompany her even in death and in the grave: "where you die I shall die, and there I shall be buried" (1:17). Ruth's ability to accompany her mother-in-law in life - "where you go I shall go"- contrasts with R. Meir's inability to remain with Elisha, ${ }^{22}$ and her vow that even death will not separate them ${ }^{23}$ is a rhetorical capstone to her commitment to accompany Naomi in life. For R. Meir, who throughout the narrative seeks to be with his master but is held back at boundaries that Elisha alone can cross, it is only in death and only after R. Meir himself will one day cross the boundary into "that other world" ${ }^{\prime 24}$ that he can anticipate finally being able to be with his master. ${ }^{25}$

Intertwined with the theme of accompaniment is the theme of place. Each character has a place where he or she belongs. But the members of the pair of characters in each story belong to different places. Much of the drama of each opening scene derives from the inability of one of the characters to enter into the other's place - and, in the case of Ruth, from her striking ability to cross into that place and make it her own. The significance of place is also dramatized in the ability or inability of each of the older figures to return to the place to which he or she once belonged. Naomi seeks to return to her original homeland, after having spent many years in Moab, the homeland of her daughters-in-law. The beit midrash once was Elisha's place, but it is no longer-as the anonymous "they"

Sinner, $356 \mathrm{n}$. 23), a meaning quite similar to $b-k-r$, though perhaps emphasizing even more the notion of accompaniment and of being in the same space. Whatever reading one adopts, this section once again highlights the theme of accompaniment and echoes the word mevakarte (to visit) that appears in the previous two sections.

22. It is striking that Ruth's commitment to go where Naomi goes is explicated in the Targum as accepting the prohibition against traversing the Shabbat boundary. The ability to walk together is imagined as the commitment to remain with the other inside the Shabbat boundary. It is this very boundary, and Elisha's lack of commitment to remain inside it, that restrains R. Meir from continuing to walk with his master.

23. This reading takes Ruth's words to mean "not even death will separate between me and you." (See discussion in Edward F. Campbell, Ruth -Anchor Bible 7 [New York: Doubleday, 1975], 74-75.) Alternatively, Ruth's words have been construed as "only death will separate between me and you." (See, for example, Frederic Bush, Word Biblical Commentary: Volume 6-Ruth-Esther [Dallas: Word Books, 1996], 82-83. Standard translations vary in how they construe the verse.) According to this latter reading, Ruth's words present a strong contrast with the aggadah: Ruth is able to be with her mother-in-law only until death effects a final separation, while R. Meir is unable to accompany his master until death effects a final reunion. I am indebted to David Silber for pointing out the resonance of this verse with the aggadah.

24. The resonance of lemivakere and/or mikrav with the words kever and boker in the preceding scene highlights that it is only in the grave and in that other world (the world that is "entirely morning") that R. Meir can anticipate finally being with his master.

25. Note that the string of ways in which Ruth describes being with Naomi includes ba-'asher talini 'alin. The use of this verb anticipates the climactic verse lini ha-laylah ..., the verse that R. Meir will recite, explicate, and enact at Elisha's grave as he anticipates a time when he will finally be able to be with his master. 
of the narrative tell R. Meir, "your master is outside."26 Though Elisha still seeks to participate in the discourse of the beit midrash-immediately on meeting R. Meir he inquires about what he had been teaching, and most of the ensuing conversation takes the form of a debate about these teachings - he is now an outsider; the beit midrash is a place to which he can no longer return. And R. Meir, now the master in the beit midrash, cannot go into what has become Elisha's place, the zone outside of the boundary of Shabbat observers.

The third theme, deeply connected with the first two, is the theme of return. The verb lashuv is a key word in the book of Ruth, occurring twelve times in the first chapter alone. Naomi sets out to return to Judah, accompanied by her daughters-in-law $(1: 6,7)$; she urges them to return to their own homes $(1: 8,11$, $12)$; they insist on returning with her (1:10). Finally, Orpah heads back, and Naomi tells Ruth that her sister-in-law has returned to her people and that she should return after her sister-in-law (1:15). Ruth refuses to turn away-also lashuv - from her mother-in-law (1:16); she is with Naomi when her mother-in-law returns from Moab (1:22), ${ }^{27}$ and she herself is later described as having returned along with Naomi from Moab (2:6).

In the aggadah, two different verbs are used for return: lashuv, in verses that are cited at critical points in each act, ${ }^{28}$ and lahzor, in the discussions between R. Meir and Elisha in which these verses are invoked. ${ }^{29}$ The theme of return is of course crucial for the aggadah. In the first act, R. Meir's third derashah talks of return to a former state, and R. Meir soon urges Elisha to return. Elisha tells him that this is impossible, as he has heard a heavenly voice proclaim "Return children [shuvu vanim (Jeremiah 3:14) $]^{30}$-except for Elisha ben Abuyah." In the deathbed scene, $\mathrm{R}$. Meir repeats his challenge in precisely the same words that he used earlier: "Will you not return?" (let 'at hazar bekha). And, in response to Elisha's query as to whether return is possible- "If one returns, is he accepted?"-R. Meir offers a derashah on a verse from Psalms-"You cause the human being to return to dust and say, 'Return, children of man!" (tashev 'enosh 'ad daka' va-to'mer shuvu vene 'adam) (Ps 90:3). While the plain meaning of the verse is that God returns human beings to dust, $R$. Meir reinterprets the verse to mean that God anticipates and encourages people's return/repentance

26. The nuance of "outside" includes both being outside in the spatial sense and being an outsider or being excluded; see the expression $h u z$ mi- in the final section of the first act.

27. One additional occurrence of this verb in the first chapter, heshivani (1:21), will be discussed below in relation to another occurrence in Ruth of the hiph 'il form of this root.

28. Note also that Job 42:10, cited by R. Meir in his first derashah, includes the words shav 'et shevut in relation to the restoration of Job. Be'eri argues that the words tuvan (mah havitah darash tuvan) and shubta (be-yom shubta) also echo the verb lashuv and the idea of teshuvah (Yaza', 73).

29. The verb also appears in the flashback about Elisha's circumcision celebration; R. Eliezer and R. Yehoshua tell Abuyah that they have been hozrin words of Torah (Rubenstein, "Elisha," 148). See Be'eri, Yaza', 201 n. 46, who cites Fraenkel's suggestion that the original reading was horzin, and that this was changed to hozrin under the influence of other occurrences of this verb in the aggadah.

30. The complete phrase is shuvu vanim shovevim - the adjective shovevim (wayward, rebellious, backsliding) shares the root of the word shuvu. The sons have turned away; God invites them to turn back/return. 


\section{Devora Steinmetz}

(shuvu, as in the verse from Jeremiah) until the last moment of life. Elisha cries as he expires, and R. Meir rejoices in the idea that his master has died repentant (mi-tokh teshuvah).

The idea of return is connected to the idea of finding one's place, both the physical space in which one belongs and the religious/national sphere that defines one's identity. Ruth's "return" to Judah is not a going back to a place from which she has come; it is a turn toward a core self that will redefine her identity_-"where you will go I will go ...; your people is my people, and your God is my God." R. Meir's plea to Elisha to turn back at the Sabbath boundary is, of course, also a plea to return to his former affiliation with the world of the beit midrash. Elisha has become an outsider: he is outside (le-var) of the beit midrash in the first scene, and he is outside (huz) of the realm of possible return in the final scene of the first act. Riding his horse outside the beit midrash in the opening scene and riding his horse outside the holy of holies in the latter scene are spatial ways of locating Elisha outside in the double sense of the word - he can neither return to the beit midrash nor to the religious world that that space represents.

\section{InCORPORATING THE OUTSIDER AND EnACTING GOD’s WiLL}

These last two themes - the idea of one's place and the possibility or impossibility of (re-)turning to that place - point to what is perhaps the most obvious parallel between the aggadah and the book of Ruth. Both tell the story of a person who is an outsider, and in both the outsider is ultimately (re-)incorporated. Crucially, Ruth and Elisha are not outsiders simply by origin or by choice. Their outsider status is affirmed by divine word, by a proclamation that makes it clear that they can never be incorporated into the community. ${ }^{31}$ Ruth is from Moab, a nation whose members are forbidden from entering into the community "forever" (Deuteronomy 23:4). ${ }^{32}$ While this directive is not mentioned explicitly in the book of Ruth, it no doubt hovers in the background of the story, like other

31. David Silber points out to me that Naomi, as well, sees herself as rejected by God $(1: 13,21)$. Yet Ruth accompanies her and, ultimately, is the instrument of her redemption (4:14). In fact, looking back at the theme of accompaniment discussed earlier, there is an apparent anomaly: in the aggadah it is Elisha who is excluded and it is R. Meir who accompanies him in the opening act, while in the book of Ruth it is Ruth who is excluded yet she is the one who accompanies Naomi in the opening chapter. Silber's insight highlights the complexity of the book of Ruth, in which both Ruth and Naomi are in need of redemption. The book begins with Ruth accompanying Naomi and then caring for her, but then Naomi works to secure a redeemer for Ruth, who becomes the source of Naomi's redemption and return (4:15 - see the discussion of meshiv nefesh, below).

32. See the discussion of possible understandings of the term lavo' va-kahal in Steinmetz, "Distancing and Bringing Near," n. 35. I take the traditional rabbinic understanding of the verse as referring to a prohibition against marriage as metonymic of a broader exclusion from the community. In Ruth, too, Boaz's marriage to Ruth stands for a more general incorporation of Ruth into the community. It is this broader notion of exclusion/incorporation that is common to our two stories. Similarly, in the aggadah about the deposition of Rabban Gamaliel in B. Berakhot 27b-28a, the question of the inclusion of Judah the Ammonite proselyte into the congregation (lavo'va-kahal) might refer specifically to the issue of marriage but nevertheless is part of a more general concern about who is included in the 
biblical laws that are assumed by the narrative, such as the rules relating to paupers gathering in the fields and to the redemption of ancestral land. Elisha too is excluded by divine word - he has heard a heavenly voice proclaim that anyone can return except for himself.

The possibility of return, then, is not just a challenge for the individual who is outside and for the community to which the person is an outsider. The possibility of return is a challenge to God's word. Somehow in each story the characters will have to find a way to incorporate the outsider despite the divine word that permanently excludes him or her. The mechanism at work in their inclusion is yet another parallel between the two stories, and this parallel points toward an exceptionally important theme in the aggadah.

A notable feature of the book of Ruth is that the characters talk about God a good deal, yet God does very little in the book. In fact, the only two acts that the narrator attributes to God are giving bread to the people who have suffered in famine, in the first chapter $(1: 6),{ }^{33}$ and giving conception to Ruth, in the last chapter (4:13). These are both gifts of fertility, ${ }^{34}$ life-giving acts that are outside the realm of human control. ${ }^{35}$ All of the rest of the action is performed by people. Nevertheless, God is repeatedly invoked by the characters. God's name is invoked in blessing $(2: 4,20,3: 10)$; characters express their wishes for others in terms of God granting them good things $(1: 8,9,2: 12,4: 11-12)$; and good things that happen are attributed to $\operatorname{God}(2: 20,4: 14){ }^{36}$

community. See Steinmetz, "Agada Unbound,” n. 27, and "Must the Patriarch Know “Uqtzin? The Nasi as Scholar in Babylonian Aggada," AJS Review 23 (1998): 163-90.

33. Though this is presented as something that Naomi has heard, the notion that God has given bread to the people seems to be the narrator's perspective, as well. It is not presented in direct speech, which could more likely be seen as reflecting the perspective of a character in the story, and the term $p-k-d$, common to other biblical narratives, is used. See, in particular, Genesis 21:1 and 1 Samuel 2:21, where the term is used in relation to the birth of a child.

34. Fertility of land and of people are deeply interwoven in this book. Indeed, the land and its seasons of harvest and grain processing are the backdrop for the story of Ruth and Boaz's meeting and the promise of their marriage in chapters 2 and 3, culminating in their nighttime encounter on the threshing floor. Conversely, famine heralds the death of Naomi's children in chapter 1. As fertility of the individual is interwoven with fertility of the land, so are private events interwoven with the national story in the book of Ruth. The book, after all, begins with the time of the Judges (1:1) and ends with the anticipation of kingship (4:17-22); the story of Naomi and Ruth bridges these eras in the nation's history. Individual, land, and nation are thus intertwined in the book of Ruth, whose narrative seamlessly zooms in and out between the story of a small number of individuals, the political development of the nation, and the agricultural seasons of that nation's land.

35. As captured nicely in B. Ta'anit 2a: Two of the three keys over which God does not relinquish control, according to R. Yohanan, are the key of rain and the key of childbirth. (The third is the key of resurrection of the dead, which restores life, as childbirth generates life.) Rain is essential for sustenance, as is made explicit in the continuation of the passage (B. Ta'anit $2 \mathrm{~b}$ ). One might see the deaths of Naomi's husband and sons - the flip side of these life-giving gifts of fertility - as also caused by God (as Naomi herself does-1:13, 20-21), but the narrator does not attribute these deaths to God.

36. Naomi's attribution of bad things to God in the opening chapter will be discussed below. 


\section{Devora Steinmetz}

The intersection of what characters in the book attribute to God and what characters in the book do themselves is crucial to understanding how the book presents the incorporation of Ruth the Moabite into the community of Israel. When Naomi first hears from Ruth about how Boaz has helped her, she offers a blessing, invoking "the Lord, who has not withheld His kindness to the living or to the dead!" (barukh hu' la-'Adonai 'asher lo' 'azav hasdo 'et ha-hayim ve'-et he-metim) (2:20). ${ }^{37}$ Earlier in the book, Naomi offers a wish for her daughters-in-law: "May the Lord perform kindness toward you, as you have performed toward the dead and toward me!" (ya'as 'Adonai 'imakhem hesed ka-'asher 'asitem 'im ha-metim ve-imadi) (1:8). Here too, Naomi presents God as one who does hesed, but God's hesed is invoked in relation to hesed that is done by human beings. It is Orpah and Ruth who have done hesed toward those who are dead and toward Naomi. Thus, the hesed that Naomi later attributes to God-hesed toward the living and the dead - is the very same kind of hesed that her daughters-in-law have done, and that in turn Naomi hopes will evoke God's hesed toward them. Later in the story, it is once again a human being who will perform hesed. When Boaz understands why Ruth has come to visit him on the threshing floor, he blesses her: "Be blessed of the Lord, my daughter! Your last kindness is better than the first ..." (berukhah 'at la-'Adonai biti, hetavt hasdekh ha-'aharon min ha-ri'shon) (3:10).

The juxtaposition of human and divine hesed in these three blessings is striking. In the first verse $(2: 20)$, it is Boaz who had done hesed toward Ruth, going well beyond the law that requires the landowner to allow the stranger to gather

37. The antecedent of the word 'asher - the identity of the person to whom Naomi is attributing the hesed - is much debated. Most translations understand the word to refer back to God. Some commentators argue that it refers to Boaz, pointing in particular to 2 Samuel 2:5, in which the word clearly has a human antecedent: "may you be blessed of the Lord, that you performed this kindness ..." (berukhim 'atem la-'Adonai 'asher 'asitem ha-hesed ha-zeh). Others cite Genesis 24:27 in support of the idea that it refers to God- "blessed be the Lord ... who has not withheld His kindness ... " (barukh 'Adonai ... 'asher lo' 'azav hasdo). See Basil A. Rebera, "Yahweh or Boaz? Ruth 2.20 Reconsidered," Bible Translator 36, no. 3 (1985): 317-27 for a strong argument that the word refers to Boaz. For discussion and review of scholarship on the question, see Bush, Ruth, 135-36 and Daniel I. Block, The New American Commentary: Volume 6-Judges-Ruth (Nashville: Broadman and Holman, 1999), 672-73. It seems to me that the Genesis verse offers a much closer parallel to our verse, as it shares the phrase 'asher lo 'azav hasdo (who has not withheld his kindness), unique to these two verses. (Yair Zakovitch points out that this phrase occurs only in these two passages; see Ruth: Introduction and Commentary [in Hebrew] [Tel Aviv: Am Oved, 1990], 28 and 83. While the Ruth and Genesis verses are strikingly similar in sharing this phrase, Rebera and Bush argue that, from a syntactic perspective, the Ruth verse is significantly different from the Genesis verse and quite similar to the Samuel verse.) And the many echoes of the story of Rebecca in the book of Ruth support the notion that this verse is intentionally echoed here. (Many scholars point out the verbal echoes between these two stories; for an extensive list of parallels, see Zakovitch, Ruth, 28-29.) It has also been suggested that the Ruth verse is intentionally ambiguous, conflating the hesed of Boaz with God's hesed, an understanding that fits well with the interpretation offered here of the interrelationship of human and divine action in Ruth. See Katherine D. Sakenfeld, The Meaning of Hesed in the Hebrew Bible: A New Inquiry (Missoula: Scholars Press, 1978), 106 and Charles Halton, "An Indecent Proposal: The Theological Core of the Book of Ruth," Scandinavian Journal of the Old Testament 26, no. 1 (2012): 30-43. 
food, and yet Ruth's encounter with Boaz is described by Naomi as an instance of divine hesed. ${ }^{38}$ Thus, in this book, people act in a way that manifests the quality that they attribute to God. Further, when people act in a way that conforms to their understanding of what is good, they are not only enacting God's will, they are acting in God's stead - or, to put it more boldly, it is God who is acting through them. ${ }^{39}$

This way of seeing human action ${ }^{40}$ enables - in fact, demands - the incorporation of Ruth into the community. When Boaz first meets Ruth, he tells her how he has heard of her actions and expresses a wish that she be rewarded by the God of Israel "under whose wings [kenafav] you have come to seek refuge" (2:12). When Ruth speaks to Boaz on the threshing floor, she says simply: "spread your cloak [kenafekha] over your maidservant, for you are a redeemer" (3:9). While the two occurrences of the word are generally translated differently, both verses refer to a person seeking refuge under another's kenafayim. ${ }^{41}$ Boaz understands that it is God who offers this refuge; Ruth challenges him to understand that it is he, Boaz, who must offer this refuge. ${ }^{42}$ Boaz is not just being challenged to act in place of God; he is enacting the act that is attributed to God: God does offer refuge to Ruth to the degree that Boaz is able to offer refuge to Ruth. Since it is God to whom the offer of refuge is attributed (2:12), it becomes the

38. Naomi's mention of hesed toward both the living and the dead and her explanation to Ruth that Boaz is a relative and potential redeemer anticipates Boaz's act of redemption and introduces that act as another instance of God's hesed.

39. This way of viewing human action in relation to God is captured well in a sentence that I heard at a conference on Jewish farming, spoken by a Christian who runs a farm whose produce is distributed to the poor. He began his speech by saying: "We serve an awesome God who works through us in such wondrous ways!" Praising God for human action implies that, when people do what they understand to be God's will, it is God who is acting. Fulfilling God's will - performing the kind of action that one attributes to God-is actually enacting God's will. Robert L. Hubbard, Jr., pointing out the paucity of actions performed by God in the book of Ruth and the frequency of characters' references to God, concludes: "The implication is that if the story presumes divine action at all, it must be through human agents." See The New International Commentary on the Old Testament: The Book of Ruth (Grand Rapids: Eerdmans, 1988), 68-69.

40. Another example of this view of human action is suggested by the language that Naomi uses to introduce her plan to Ruth at the beginning of chapter 3. Naomi tells her daughter-in-law that she is seeking a manoah for her (3:1); this echoes the wish that she expressed to her daughters-in-law in chapter 1 that God enable them to find menuhah in their husbands' homes (1:9). Thus, Naomi herself ultimately arranges what she hopes God will arrange. Campbell (Ruth, 81) sees this as one example of the notion that, in Ruth, "divine will and human action go hand in hand," and Tamara Cohn Eskenazi (The JPS Bible Commentary: Ruth [Philadelphia: JPS, 2011], li) cites this as an example of Tikva Frymer-Kensky's observation that "the characters in [the] Book of Ruth themselves act to fulfill the blessing that they bestow on one another in God's name."

41. For whether the word in the latter verse should be construed as singular or plural, see Bush, Ruth, 164-65. The singular is generally understood as connoting garment and alluding to marriage, and the plural as connoting wings and signifying protection. Nevertheless, whether one sees the term that Ruth uses as referring directly to marriage or as asking for protection, the implication is the same: in either case, Ruth is suggesting that Boaz offer her refuge by acting as redeemer and marrying her. And, in either case, this verse clearly echoes the earlier verse about God offering refuge.

42. I am indebted to David Silber, who first pointed this out to me. 


\section{Devora Steinmetz}

task of the human being who recognizes this characteristic of God to enact it. Boaz, then, cannot possibly be seen as acting in a way that is counter to God's will, because he does nothing other than enact the very will that God - the one under whose kenafayim refuge is sought - is imagined to manifest.

This scene - in which Ruth convinces Boaz to enact God's attribute of offering refuge, effectively challenging God's exclusion of the Moabite-is the very scene that $\mathrm{R}$. Meir enacts in the aggadah, as he challenges God to redeem Elisha. R. Meir suggests that it is really God's job to act as redeemer. Playing with the syntax of the verse from Ruth, R. Meir construes the word tov (good) as the subject of the verb "to redeem." And R. Meir interprets the word tov as referring to the one who is good, that is to God. And how does R. Meir know that God is good? Because of another verse that describes God in this way: "The Lord is good to all, and his compassion is upon all of his creations" (tov 'Adonai la-kol ve-rahamav 'al kol ma 'asav) (Psalms 145:9). This verse not only describes God as good, it describes God as good la-kol (to all) and as compassionate la-kol (to all). ${ }^{43}$ In the context of the derashah on the verse from Ruth, R. Meir is saying that God - the God who is good to all - is the one who ought to redeem Elisha. No one is excluded from God's goodness and compassion; la-kol stands in direct contradiction to huz mi-. Though Elisha has heard a divine voice offering the possibility of return to everyone except for him, R. Meir recalls a verse that says that there are no exceptions to the recipients of God's goodness. ${ }^{44}$

As in the story of Ruth, it is recognition of an attribute of God that both enables a human being to enact that attribute and empowers him to perform an action that appears to be contrary to God's own word. R. Meir, offering to be the redeemer himself, challenges God to perform the role of redeemer. Looking at the aggadah in relation to Ruth, we might see R. Meir's offer to redeem Elisha as in fact enacting God's redemption. When the fire dies down at the conclusion of this scene, it is not entirely clear whether it is R. Meir's act of covering the grave with his cloak that has subdued the fire-literally, snuffing out the fire with his cloak, and figuratively, as the redemptive enactment of $u$-farasta

43. The word $k o l$ is the key word in this psalm, occurring seventeen times in a chapter of twenty-one verses.

44. It is worth noting the juxtaposition in Psalm 145 of hesed and goodness. Verse 9, the verse cited in R. Meir's exegesis in order to demonstrate God's goodness, is part of a two-verse description of God's attributes, which begins with verse 8: "Gracious and merciful is the Lord, slow to anger and great in hesed." These two verses, in turn, are introduced in verse 7: "They shall utter the mention of your abundant goodness ...." Thus, verses 8 and 9 spell out the goodness mentioned in the preceding verse. Verse 8, of course, echoes the attributes of God stated in Exodus 34:6: “... merciful and gracious, slow to anger and abundant in hesed ... ." Verse 9 extends this conventional description of God's attributes, emphasizing that God's goodness and God's mercy extend to all. In Psalm 145:7-9, then, God's hesed, as well as God's other compassionate attributes, are introduced by a general reference to God's goodness, of which they are an expression, and followed by yet another reference to God's goodness and the assertion that this quality extends to all of God's creations. Reuven Kimelman offers a helpful analysis of the structure of Psalm 145 in "Psalm 145: Theme, Structure, and Impact," Journal of Biblical Literature 113, no. 1 (1994): 37-58; Kimelman describes verses 7-9 as "a triad on the theme of God's goodness" and notes the echo of the divine attributes of Exodus 34:6 in verse 8 of the psalm. 
kenafekha - or whether God has accepted the challenge and decided to redeem Elisha. Given that the fire's extinction occurs now, rather than in the future time in which R. Meir promises to redeem Elisha if God refuses to do so, it would appear that God has indeed acceded to R. Meir's challenge. ${ }^{45}$ In light of the way human action and divine will interact in the passage in Ruth, perhaps one should conclude that God has redeemed Elisha through R. Meir's act of redemption.

\section{EXEGESIS AND ACTION}

It is important to recognize that $\mathrm{R}$. Meir's ability to redeem Elisha occurs both through action and through interpretation. R. Meir's enactment of the verse is accompanied by an exegesis that explains the meaning of his action and serves as the rationale for his action. And his interpretation of the verse is, in turn, dependent on another verse that is essential to R. Meir's construal of the word tov in the Ruth verse as referring to God as the one who ought to redeem Elisha, since God is the one whose goodness extends to all.

It is the possibility of interpretation, then, that allows R. Meir to redeem his teacher. In fact, exegesis of Scripture is a recurring motif in this aggadah. The first act focuses on R. Meir's exegesis of three verses, the first two of which are contested by Elisha. ${ }^{46}$ In the scene before the one in which R. Meir interprets and

45. Although R. Meir seems to see the possibility of God's redemption also as taking place in a future time: "and it will be in the morning - that is the world to come that is all morning" (ve-haya va-boker-zeh ha-'olam ha-ba' she-kulo boker). Of course, in the Ruth story, it is only in the morning that the go'el (redeemer) who is first in line is given the opportunity to redeem Ruth. Ruth will not be redeemed at night, though it appears that Elisha is, despite R. Meir's assumption that his redemption will need to wait until "morning."

46. In the Yerushalmi, Elisha does not contest R. Meir's third exegesis. In the Ruth Rabbah parallel, he does: following the pattern of the first two derashot, R. Meir offers an interpretation of the verse, and Elisha offers a competing interpretation in the name of R. Akiva. That is, the exegesis found in the Yerushalmi is divided in Ruth Rabbah into two parts - the section about the fragility of the vessels is offered by R. Meir, while the part about the restorability of the vessels is stated by Elisha in R. Akiva's name. The Ruth Rabbah version conforms to the Bavli, in which the exegesis of the verse about gold and glass is the second of two exegeses of verses, in both of which Elisha counters R. Meir's interpretation by offering an interpretation that he attributes to R. Akiva.

The Yerushalmi and Ruth Rabbah versions have different dramatic qualities. In the Yerushalmi, Elisha appears to be trapped at this point; he has no response to R. Meir's exposition about the restorability of the vessels, and he terminates the discussion at this juncture: "Enough, Meir!" (See Avraham Walfish, "Ha-hipus 'ahare Elisha ben Avuya ha-sifruti ve-ha-histori," Katarsis 11 [2009]: 23-57, at 9-10 and Goshen-Gottstein, Sinner, 179.) In Ruth Rabbah, in contrast, he himself has been cornered into offering the interpretation about the restorability of vessels, as part of the sequence of his contesting R. Meir's exegeses by offering those of R. Akiva. (And here he immediately follows the claim that a scholar can return [lahazor] to his learning with the statement that R. Meir should return [hazor].)

The two exegeses attributed by Elisha to R. Akiva in the Yerushalmi are odd. Given the traditional portrait of R. Akiva as himself a person who underwent radical transformation, it seems uncharacteristic to attribute to him teachings that suggest that one's past is determinative of one's future. The exegesis about the restorability of vessels, on the other hand, would seem more in line with what one might expect to find attributed to R. Akiva. (And compare R. Meir's teaching on tov 'aharit davar with 


\section{Devora Steinmetz}

enacts the Ruth verse, R. Meir bases his assertion that Elisha can still return on an exegesis of a verse from Psalms. And, in the interlude that includes three explanations of what caused Elisha to go astray, the first explanation attributes this to Elisha taking a verse literally and noticing that the verse is untrue in the face of the reality that he has observed. ${ }^{47}$ Elisha, the narrator tells us, did not know the derashah offered by a different sage, an interpretation of the verse that would have allowed this piece of Torah to speak truth within the real world of human experience. ${ }^{48}$ This derashah, like R. Meir's exegesis of the Ruth verse, hinges on a form of the word tov, a point to which I will return shortly.

Exegesis of Scripture, in this aggadah, is deeply personal. Elisha asserts this himself, as he concludes his report of R. Akiva's alternative interpretation of R. Meir's second verse- - The end of a thing is better than its beginning" (tov 'aharit davar me-re'shito) - by saying "and this incident happened to me" (u-vi hayah ma'aseh) and telling the story of his own beginnings. All three of the opening derashot speak to Elisha's situation, and the contesting interpretations of the first two verses speak not only to Elisha's and R. Meir's different understandings of Scripture, but to their different understandings of reality, in particular of the human condition. Words of Torah, in this story, must correspond to the lives that real people lead, and so verses that cannot be true to the way one experiences the world must mean something different from what they appear to mean on the

the teaching of R. Yehoshua and the related story about R. Akiva on B. Yevamot $62 \mathrm{~b}$. This story of restoration late in R. Akiva's life conforms to the notion of transformation that shapes each of the traditions about R. Akiva's early life, and it is linked to a teaching that is similar to R. Meir's exegesis of Ecclesiastes 7:8, which is reported by Elisha to be opposed to R. Akiva's transformation-denying teaching on that verse.) See Walfish, "Ha-hipus," 9, for the suggestion that Elisha might be understood as inaccurately representing R. Akiva's teachings in line with his own perspective. See also GoshenGottstein, Sinner, 133-36, for a discussion of the exegeses in the Bavli.

47. Goshen-Gottstein argues against seeing this episode as only about theodicy. He notes the significance of the fact that "Elisha sees them [i.e., these events] while engaged in Torah study. The problem becomes related to Torah study or falsification of Scripture. The ... problem is the veracity of the scriptural message" (Sinner, 196).

48. The final two scenes of the aggadah also include citations of texts. In the penultimate scene R. Meir cites a tannaitic source and applies it metaphorically to Elisha. In the final scene Rabbi cites a verse to justify his refusal to support Elisha's daughters, and the daughters make a counterargument that focuses on Elisha's Torah, like R. Meir's argument in the preceding scene. In this one case, no alternative interpretation of the verse is offered. Nevertheless, once again the application of the verse in its literal meaning is contested in a successful effort to incorporate those who are excluded.

Note that this final verse, Psalms 109:12, denies the extension of hesed and graciousness to the orphans of the wicked person. From the perspective of Psalm 145, this limitation on the objects of God's hesed and graciousness is out of the question. If God's goodness (145:7) is expressed in hesed and graciousness (145:8), and if that goodness extends to all (145:9), then the orphans of the wicked cannot be excluded from this goodness and hesed. Thus, the verse that R. Meir cites-tov 'Adonai la-kol - continues to resonate throughout the end of the aggadah, as the initial refusal to extend hesed to Elisha's orphans is reversed. Once again, God's goodness, and the conviction that this goodness extends to all, negates the possibility that anyone - whether Elisha himself or his daughters-is excluded from God's hesed and graciousness. 
surface. To fail to interpret Scripture in this way, as Elisha failed to do when he saw the death of the man who observed the law that Scripture promises will be rewarded by goodness and long life, would be to abandon Torah. For R. Meir, making Torah true requires both interpreting Torah in a way that speaks to one's core experience and acting in a way that makes the promises that one reads in Torah become true.

As Elisha and R. Meir begin their walk together, R. Meir offers two expositions of scriptural verses that Elisha contests. While some scholars have pointed to the simplicity of R. Meir's teachings, to his failure to offer clever interpretations, ${ }^{49}$ it seems to me that R. Meir is not attempting to reinterpret Scripture but rather to draw out what he understands as the core message of these scriptural passages - that, no matter how awful things are in the beginning (as in the case of Job, in the first derashah), the end can always be better (as in the second derashah, from Ecclesiastes). Note that his second derashah is on a verse that includes the word tov-tov 'aharit davar me-re'shito. This derashah, then, sets the stage for the other derashot that focus on the word tov: the derashah that Elisha does not know, causing Elisha's failure to see the tov that awaits one who follows God's law, and the derashah that R. Meir enacts at Elisha's grave, ensuring that Elisha's end will be tov. ${ }^{50}$

If R. Meir believes, as the verse from Ecclesiastes teaches, that the end is better-tov - than the beginning, then what R. Meir does through his exegesis and enactment of the Ruth verse at Elisha's grave is to make his teaching about the Ecclesiastes verse true. Through his interpretation of the Ruth verse- "if he will redeem you, good" ('im yig'alekh tov) - by means of the Psalms verse - "The Lord is good to all" (tov 'Adonai la-kol) - R. Meir has indeed made the end better than the beginning. It bears emphasizing that he makes the teaching from Ecclesiastes true both through interpretation and through action - bringing the meaning of the scriptural verses, as he has understood them, to life. If it is true that the end will be better than the beginning, and if it is true that God is good to all, then God must redeem Elisha. If God will not, then R. Meir will make God's own words true through his own enactment of what it is God's to do.

Thus, among other things, this aggadah is a story about how one lives out the Torah that one learns and how one learns Torah in relation to lived experience.

49. Rubenstein, "Elisha," 155-56; Be'eri, Yaza', 53, 56. See Walfish, "Ha-hipus," 9, for a counterargument.

50. Rubenstein notes that all three exegeses work with the word tov; he also notes that the derashah that Elisha did not know and R. Meir's derashah on the Ruth verse both make a distinction between this world and a future world. "Ironically," Rubenstein comments, "Elisha is saved by an exegesis and theological argument based on the very distinction that he did not know, which caused his loss of faith and damnation" ("Elisha," n. 47). Note also that these two derashot claim that we can anticipate a world that is "wholly" (kulo) positive (she-kulo tov / she-kulo boker-the parallel is even clearer in Ruth Rabbah, where the future world in R. Meir's derashah is described as she-kulo tov, exactly as in the earlier derashah). The idea of something that is "wholly" good resonates with the verse from Psalms that R. Meir cites in support of his exegesis of the Ruth verse-tov 'Adonai la-kol ve-rahamav 'al kol ma'asav. 


\section{Devora Steinmetz}

What is accomplished in Ruth through enacting the qualities and actions that are attributed to God, is accomplished in the aggadah through enacting those qualities and also through explicit reinterpretations of Scripture that allow Torah to be true and real. In both stories, the quality of goodness or hesed that is attributed to God (in the aggadah through the citation of a biblical verse that establishes this quality) dictates how human beings need to behave, even in the face of divine proclamations that would seem to exclude someone from this goodness. R. Meir, like Boaz, can redeem because he is convinced that his act of redemption is consistent with God's core attribute of goodness.

\section{TOV 'AHARIT DAVAR ME-RE'SHITO}

Many stories come to a happy resolution of what appears to be a hopeless situation, but in both Ruth and the aggadah the idea of a good ending is one of the themes of the story. The aggadah, as I have noted, introduces the idea through R. Meir's citation of the verse from Job, which speaks specifically of the experience of that biblical figure, and then of the verse from Ecclesiastes-"The end of a thing is better than its beginning" (tov 'aharit davar me-re'shito) - which speaks in universal terms. This second verse introduces the quality of goodness, which will be critical to the unfolding of the story, as other derashot are offered on verses with forms of the word tov, and as R. Meir strives to generate an outcome that is consistent with God's goodness and with the expectation that the ending will be good.

The word tov is also important in the book of Ruth. It does not appear at all in the first part of the story. On the contrary, at the end of the first chapter Naomi describes her situation to the townswomen, who have expressed shock at the state in which she returns to Bethlehem, as the antithesis of tov: "Shaddai has done evil to me" (ve-Shaddai hera ' $l i)(1: 21)$. It is only as the first half of the narrative draws to a close, when Naomi learns of Boaz's kindness and recognizes that the person who has treated Ruth so kindly is a potential redeemer (2:20), that she uses the word tov, as she instructs her daughter-in-law to remain in Boaz's field $(2: 22){ }^{51}$

51. Naomi uses this word in the context of instructing Ruth to stay with Boaz's young women. This is in striking contrast to Ruth's report, in the preceding verse, that Boaz has told her to stay with his young men, using the word tidbakin (2:21). Indeed, Boaz had told Ruth to stay (tidbakin) with his young women (2:8). The verb that Boaz uses and that Ruth accurately repeats is the word used to describe the union of a husband and wife in Genesis 2:24. Naomi's replacement of Ruth's suggestion that she be with Boaz's young men with the instruction that she be with his young women-coming right after Naomi has told Ruth that Boaz is a redeemer (2:20) - might suggest, beyond concern for Ruth's safety or chastity, that Naomi is already anticipating the possibility of Boaz marrying Ruth. If so, then the use of the word tov in relation to her instruction to Ruth might be an echo of Genesis $2: 18$ - "it is not good [tov] for the human being to be alone"- which introduces the events that culminate with the creation of woman and the observation that a man cleaves (ve-davak) to his wife. Naomi's use of the word tov in this context, then, anticipates that Ruth and Boaz will marry and coincides with the first glimmer that the $r a$ ' that Naomi has experienced will be reversed by means of this marriage and a child that it might produce.

I am indebted to David Silber for the observations about the switch between young men and young women in relation to the use of the word tidbakin. Silber also points out the echo of Genesis 
After this, forms of the word tov appear with notable frequency: four times in the coming chapter $(3: 1,7,10,13)$, culminating with "if he will redeem you, good" (3:13). The final occurrence of the word is toward the very end of the book, as the townswomen once again comment on Naomi's state and describe Ruth as "better to you than seven sons" (tovah lakh mi-shiva " banim) (4:15). ${ }^{52}$

The story, then, has moved from $r a$ ' at the beginning to tov at the end. Moreover, the townswomen's comment that Naomi's daughter-in-law is better to or for her than seven sons suggests that Naomi is not only better off now than in the sorry state in which she returned to Bethlehem; she is, in some sense, better off now than she was at the beginning, when her family was intact and her sons were alive. ${ }^{53}$

From the vantage point of the aggadah, the most striking occurrence of a form of the word tov in the book of Ruth is in Boaz's words to Ruth when he discovers her lying next to him on the threshing floor: "Your last kindness is better than the first" (hetavt hasdekh ha-'aharon min ha-ri'shon) (3:10). Note that this verse juxtaposes hesed and tov, and that Boaz praises Ruth for making her latter hesed better (tov) than her former hesed. Once again, as in the broader story of Ruth and in the aggadah, something that happens later is better than something that happens earlier. Moreover, if one reads the aggadah in relation to Ruth, one can now hear that the verses that R. Meir cites early in the aggadah-both of which compare the 'aharit with the re'shit-resonate with this verse from Ruth. The book of Ruth and the aggadah share the language of 'aharit/'aharon and

2:24 in the continuation of Boaz's conversation with Ruth in chapter 2: "you have left your father and mother"; compare "therefore a man leaves his father and mother and cleaves [ve-davak] to his wife."

52. Forms of the word tov appear six times in all in Ruth, and a form of the word $\mathrm{ra}$ ' appears once, for a total of seven occurrences. Campbell, Ruth, 164, notes the importance of forms of the word tov in Ruth. The idea that the final occurrence of this word might be seen as the last in a series of seven $\mathrm{ra}$ /tov words might be strengthened by the proximity of this final occurrence to the word "seven"; see Devora Steinmetz, From Father to Son: Kinship, Conflict, and Continuity in Genesis (Louisville: Westminster/John Knox, 1991), 194 n. 23, for an example of the highlighting of the occurrence of the last in a significant number of appearances of a word by mention of the number that corresponds to these occurrences. It is worth considering whether this marked use of the word tov and its contrast with the $r a$ * that Naomi experiences in the first chapter should be seen as echoing the opening chapters of Genesis, especially as other phrases from Genesis appear in significant ways in Ruth. Note also that forms of the root $y-d-$ ' appear many times in Ruth; $y-d-$ ', of course, is a critical root in chapters 2 and 3 and in the beginning of chapter 4 of Genesis-Adam "knows" Eve and she gives birth to a child. The root first appears in Ruth as Boaz is introduced in 2:1, and it appears frequently in chapter 3 through the beginning of chapter 4, in the context of the arrangement of Ruth's marriage to Boaz.

53. The townswomen's mention of seven sons, while possibly simply a hyperbolic use of a standard number of fullness (see, for example, 1 Samuel 2:5, cited by Zakovitch, Ruth, 114), might also recall Job, who has seven sons; see Job 1:2 and 42:13. Whether or not one sees Ruth as echoing Job (see Zakovitch, 30-31, for a list of commonalities between the two books), it is intriguing to consider whether the aggadah reads the Ruth verse in this way, since the first verse that R. Meir explicatesva-'Adonai berakh 'et 'aharit 'Iyov me-re'shito - speaks of Job's loss and restoration and immediately precedes the verse that describes his regaining seven sons. Interestingly, B. Bava Batra 14a juxtaposes the books of Ruth and Job, noting that both describe terrible events but that in Ruth there is (a good) 'aharit. This is particularly striking, because a good 'aharit is explicitly mentioned in Job. 


\section{Devora Steinmetz}

re'shit/ri'shon, and both make the claim that the former is more tov than the latter. ${ }^{54}$ Returning to the aggadah, it is important to note that, while I have described R. Meir's and Elisha's interpretations of biblical verses as deeply personal and as needing to be true to lived experience, the aggadah does not suggest that how one ought to interpret Torah is entirely subjective - that R. Meir's and Elisha's readings are equally valid. That the end is better than the beginning in this story, that at the critical moment R. Meir is able to invoke his understanding of God's goodness to redeem Elisha and to make his end tov, suggests that the aggadah takes a stand on R. Meir's and Elisha's core convictions and, thus, on their interpretations of Torah. ${ }^{55}$ While both characters seem to believe that Torah must be read in a way that is true and real, the challenge presented by the aggadah is how to read and act in such a way that it is specifically the goodness that Torah describes that is seen as a possibility and enacted as a reality. ${ }^{56}$

Similarly, in the book of Ruth, while Naomi describes God as having done $\mathrm{ra}$ ' to her, her own and other characters' conviction that God is the author of hesed and that the good actions of human beings are an expression of that hesed is what ultimately allows Naomi herself, in the beginning of the third chapter, to initiate action that ensures that goodness and hesed will result. Here, too, characters read God's intention in relation to their own experience, but ultimately it is the core divine attributes of hesed and goodness that guide human action and, thus, that are manifested as the events of the book unfold. And here, too, the narrative takes a stand. Only life-giving acts are attributed to God by the narrator; the famine at the beginning of the book and the death of Naomi's husband and sons are not. ${ }^{57}$

54. It is noteworthy that forms of the word 'ahar appear frequently in Ruth, most often situating Ruth behind or after someone; see 1:15, 16;2:2, 3, 7, 9; 3:10 (and 2:11, situating Ruth's actions after a prior event). Boaz, too, as he initiates the discussion that leads to him redeeming Ruth, describes himself as 'ahare the man who has priority as redeemer (4:4). Along with ha-'aharon in 3:10, describing Ruth's act of hesed, there are a total of ten occurrences of forms of 'ahar. All but the last relate to Ruth; Boaz's final reference to himself as 'ahare perhaps signals that he is the proper match for Ruth.

55. Similarly, the narrator's comment that Elisha did not know the derashah on le-ma 'an yitav lakh does not suggest that Elisha simply disagreed and that there are two valid ways to understand this verse; rather, the comment suggests that Elisha would not have been led astray had he only known how to read this verse in a way that allowed him to see that tov would come in the end. Here, too, the aggadah sides with a reading that ensures tov and against Elisha's inability to see the good that will come.

56. And, as noted earlier, to fail to do so leads to the abandonment of Torah, as happened as the result of Elisha's failure to interpret the verse promising goodness to the one who fulfills the commandment of sending away the mother bird. Le-ma 'an yitav lakh means that there must be a world in which goodness will prevail; it is the task of the reader of Torah to discover such a world by means of interpretation (and, later in the story, by means of both interpretation and action). It is striking that, in that flashback, Elisha has given up on the possibility of Torah speaking to the reality that he has witnessed, yet in the opening scene he is still committed to relating words of Torah to his experience and, in fact, he actively reinterprets biblical verses to make it do so. Yet, in both scenes - the flashback in which he reads the verse literally and the opening scene in which he creatively reinterprets Scripture- he reads in a way that denies tov.

57. Zakovitch, Ruth, 9. 
And the trajectory of the book from devastation to redemption and new life attests to the book's stance on divine and human hesed and on the reality of goodness.

\section{Restoration through CHILDREN}

Both the aggadah and the book of Ruth end by focusing on the protagonists' child or children. The aggadah ends with Elisha's daughters going to Rabbi for charity. Rabbi refuses to support them, citing a verse from Psalms: "Let there be none to extend kindness to him, nor any to be gracious to his orphans" ('al yehi lo moshekh hesed ve-'al yehi honen li-yetomav) (109:12). ${ }^{58}$ Elisha's daughters convince Rabbi to focus on Elisha's Torah rather than on his deeds, and Rabbi changes his mind and decrees that these women are to be supported. Thus, at the very end of the aggadah, Elisha's redemption is in a sense reaffirmed through the incorporation of his children - if the psalm speaks of the cutting off of the condemned person's posterity ('aharit) (109:13), then the decision to incorporate the children is tantamount to a decision to acknowledge Elisha's membership in the community. And it is noteworthy that here, for the first time in the aggadah, the acceptance of Elisha is not R. Meir's private acceptance of his master; it is the decision of the leader of the community. ${ }^{59}$ For the first and only time, the aggadah

58. Several elements of this psalm resonate with our story, as Be'eri notes (Yaza', 201-2 n. 52):

- the mention of 'aher (7 and 13) (noted also by Goshen-Gottstein, Sinner, 360 n. 47, citing Moshe David Hoffman) — note that this epithet for Elisha is mentioned in the aggadah immediately preceding the episode about Elisha's daughters;

- the occurrence of 'aharit (13) — resonating with tov 'aharit davar - in the psalm the 'aharit, the children of the sinner, are cut off, while Elisha's daughters will have to convince Rabbi that they should not be cut off. The parallelism of 'aharit and 'aher in this verse highlights the possibility that the occurrences of the word 'aharit in our aggadah should be seen as an echo of the name Aher, as suggested by Be'eri, 51 and 71, and Goshen-Gottstein, 180;

- the reference to sins of the fathers and mother (14)_resonating with the flashbacks about each of Elisha's parents that are presented as evidence of Elisha's bad beginning or as cause of his going astray;

- "may their names be blotted out in the next generation" (be-dor 'aher yimah shemam) (13)—suggesting erasure of a name, as the sobriquet Aher might be understood to be doing - and note the theme of restoring a person's name in Ruth $(4: 5,10)$, the focus on names at the end of the book $(4: 17,18-22)$, and the erasure of the name of the potential redeemer $(4: 1)$.

It is possible that the citation of Psalms 109:12 in our aggadah is designed to invoke these resonances from the verse's immediate context. Note, also, that the verse focuses on hesed, the word that, along with tov — our aggadah's key word — is central to the book of Ruth.

59. Rubenstein entertains the possibility that "Rabbi represents patriarchal authority and therefore 'official' rabbinic institutional policy" and that this scene "therefore signals Elisha's complete rehabilitation within the general rabbinic community," but he feels that it is difficult to ascertain the significance of Rabbi here "because we do not know exactly what Rabbi Yehuda ha-Nasi represented to the storytellers and the audience" ("Elisha," 169 n. 58). It seems to me that Rabbi's decree that the daughters be supported makes it clear that Rabbi appears here in his role as leader of the community. Rubenstein suggests, instead, that Rabbi's significance in our aggadah is as R. Meir's disciple and, thus, as the disciple of Elisha's disciple, and he sees this scene as continuing a theme of spiritual sonship, alluded to most clearly in the preceding segment of the aggadah, in which R. Meir puts Elisha, his 


\section{Devora Steinmetz}

zooms out from the intimate relationship between R. Meir and his master to look at Elisha's place within the broader community. Until now, in fact, no other character has appeared within the core narrative, other than the anonymous "they" who report events concerning Elisha to R. Meir or that question R. Meir about his relationship with his master. ${ }^{60}$

The narrative of the book of Ruth ends as Ruth gives birth to a child - a child who, in the words of the townswomen, will be a meshiv nefesh (restorer of life) for Naomi. This phrase loops back to the key word of the first chapter, lashuv (return), which described Naomi's return to the land along with her daughter-in-law. In fact, the only other hiph 'il form of the verb in the book occurs in Naomi's response to the townswomen as she returns to Bethlehem: "the Lord has brought me back empty" (ve-rekam heshivani 'Adonai) (1:21). ${ }^{61}$ The townswomen's later use of the causative form of the verb closes the circle of the narrative, as the woman who returned to her land but imagined herself as living the rest of her life empty $(1: 21)^{62}$ and without hope for the future, now has a grandchild who will redeem her (4:14) and restore (literally, "return") her life. The return of Naomi as well as the incorporation of Ruth is consummated with the welcoming of the child into the community.

\footnotetext{
"spiritual father," before his father (169-70). While I am not convinced that Rabbi appears here as Elisha's “'spiritual' (grand) son” (170), Rubenstein's insight about R. Meir as Elisha's spiritual son, in an aggadah that repeatedly revisits the theme of parenthood (Rubenstein notes the two flashbacks about Elisha's parents, the question about whether R. Meir will visit his father or his master first, and also the mention of the practice of sending away the mother bird), is compelling. Elisha's restoration, then, comes not only through his children (his daughters), but through his spiritual child (R. Meir). Indeed, Rubenstein notes that R. Meir's exegesis of the Ruth verse and his interpretation of M. Shabbat "demonstrate that Elisha's Torah yielded pious disciples who studied 'for the sake of heaven.' Meir, in other words, is both the means of, and justification for, Elisha's salvation" (167).

The idea of a kind of spiritual sonship is present in the book of Ruth as well. Obed is declared by the neighborhood women to be Naomi's child (4:17), though he is actually Ruth's child. And Ruth herself, as the women point out, takes the place of Naomi's children (4:15).

60 . Both the aggadah and the book of Ruth have a kind of chorus of anonymous bystanders, offering a blurry communal backdrop to scenes that are intensely private and that are largely constituted by dialogues between two individuals.

61. Bush, Ruth, 257, points out this inclusio.

62. Note that the word "empty" recurs at the end of chapter 3, when Ruth reports to Naomi that Boaz has given her grain so that she not return "empty" to her mother-in-law (3:17). Zakovitch (Ruth, 10) sees this as another example of the juxtaposition of what characters expect from God and what characters do themselves. The two appearances of this word also reinforce the juxtaposition in Ruth between fertility of the land and fertility of people: Naomi returns from Moab "empty" of children, and Boaz makes sure that she will not be "empty" of grain. This juxtaposition suggests that Boaz's gift to Naomi of grain, carried by Ruth, serves as a promise that he will assume the role of redeemer and will beget a child (whom the neighbors will declare to be Naomi's - 4:17) through Ruth. (See Zakovitch, Ruth, 99, who points out that, since Naomi first experienced lack of food and then loss of children, Boaz's supplying her with food generates the anticipation that he will ensure the birth of a child.)
} 
Both the incorporation of Ruth into the community through her marriage to Boaz and the welcoming of the child who restores both Ruth and Naomi are affirmed by the members of the community. Boaz gathers ten elders together to witness his commitment to act as redeemer (4:2). Soon, "all the people" participate (4:9), serving as witnesses and offering a blessing that assimilates Ruth to the model of the biblical matriarchs who "built ... the house of Israel" (4:11). And finally, the women offer words of blessing, acknowledge the new life granted to Naomi, and give the child a name $(4: 14-15,17)$.

Both stories, then, conclude with the incorporation of the child/ren of the outsider by the community. The private worlds of Elisha and R. Meir and of Naomi, Ruth, and Boaz broaden to encompass the larger communal context, and the individual whose inclusion was in doubt is assured a place in the community's future through his or her child/ren. Just as Naomi's (and Ruth's) return is complete with the birth of the child who is meshiv nefesh, Elisha's return to a place in the community, if only after death, takes the form of the acceptance of his daughters by Rabbi.

\section{HESED AND GOODNESS}

Before concluding, I will address an issue that arises from the interpretation I have offered of the mechanism at work in the incorporation of the outsider in each of these narratives. In both stories, the exclusion of the outsider is affirmed by the divine word. In the background of Ruth is the biblical prohibition against a Moabite entering into the community. In the aggadah, Elisha reports having heard a heavenly voice explicitly excluding him from the possibility of return. Yet in neither story is the divine injunction ever addressed. This is perhaps not surprising in the case of Ruth, since the law against the inclusion of Moabites, like the other biblical laws that form the backdrop of the narrative, is not explicitly mentioned in the story. Nevertheless, one might wonder how the book would have its readers understand the violation of the biblical word that Boaz's marriage to Ruth represents. ${ }^{63}$ And the aggadah never addresses the heavenly voice that proclaims

63. According to the standard rabbinic interpretation, the biblical injunction refers only to the exclusion of males, not to female Ammonites and Moabites. This is reflected, for example, in both the Targum (on 2:11) and Ruth Rabbah (on 4:1), which see this rule as already known by Boaz; thus, according to these interpretations, Boaz knows that he is not violating a commandment that would require Ruth's exclusion. In contrast, the Bavli describes this ruling as first becoming public during the lifetime of David, Ruth's descendant (B. Yevamot 76b-77a). When Saul becomes nervous that David might one day rule as king, Doeg points out that, rather than inquire as to David's eligibility for kingship, Saul should consider that the young man might not even be eligible lavo'va-kahal - after all, his maternal ancestor was a Moabite. In reply, Abner cites a ruling that the prohibition applies only to Moabite males, which generates a debate as to the correctness of this interpretation. Ultimately, an inquiry is posed to the beit midrash, which confirms Abner's ruling, but Doeg persists in his counterarguments, and the beit midrash falls silent, unable to defend its ruling. As David is about to be declared outside of the community, Amasa's father boldly asserts that he has a tradition from the beit din of Samuel that the biblical exclusion applies only to males, confirming Abner's ruling and allowing David to remain a member of the community. 


\section{Devora Steinmetz}

Elisha's exclusion. While it includes several citations and interpretations of biblical verses in favor of goodness and the possibility of redemption and return, it leaves unspoken an explicit response to or reinterpretation of the divine word that Elisha understands to have declared the impossibility of his return.

It could be argued that Elisha's report of having heard the heavenly voice does not accurately reflect the facts of the narrative. Perhaps Elisha only believes that he heard this voice - hearing the exclusion that he believes to be permanent and irreversible proclaimed from the holy of holies as he rides by on the Day of Atonement - but the narrative does not suggest that such a heavenly message was ever delivered.

Alternatively, it is possible that the narrative suggests that Elisha did hear a heavenly voice, but heard it proclaim only the words of Jeremiah, "Return children" (shuvu vanim) and that Elisha interpreted these words as including all of God's children except for himself. ${ }^{64}$ This would represent yet another case of

While it is possible that the Bavli is suggesting that Samuel was transmitting a traditional ruling rather than deciding a point of law, and thus that Boaz might have been familiar with this very law, it seems more likely that the Bavli portrays the question about the inclusion of female Moabites as only becoming pertinent—and only being resolved — when David's status is at stake. At this point the issue becomes politically critical, and the law is debated in the presence of the king by his advisors and military men. It is finally resolved by reference to a ruling by the court of Samuel, the one who had anointed David as king. By locating the debate and the ruling in the time of Samuel, Saul, and David and in relation to the political issue of David's competition for Saul's throne, the Bavli implies that the matter of Ruth's inclusion was simply not an issue earlier. As this Bavli passage imagines the story, Boaz simply incorporated Ruth into the community without attempting to resolve the act's contravention of the biblical law.

In contrast, B. Ketubbot $7 \mathrm{~b}$ portrays Boaz as responsible for the interpretation that excludes female Moabites from the prohibition; R. Abbahu explains Boaz's gathering of the ten elders (Ruth 4:2) as a mechanism for enabling and publicizing this new ruling. According to this passage, Boaz does take care to address the biblical prohibition. Nevertheless, the passage does not suggest that the ruling allowing marriage to female Moabites was already in place. Rather, Boaz creates this ruling, by means of an interpretation of the biblical verse, in the context of his decision to marry Ruth. (The Yerushalmi discussion of M. Yevamot 8:3 [9c], where the exclusion of female Moabites from the prohibition is articulated, also depicts the law as coming into being during the events of the book of Ruth, though there it is suggested that the innovation immediately preceded Ruth's appearance in Boaz's field. See also Ruth Rabbah on 1:21 and 2:11.)

Both Bavli passages, then, seem to avoid suggesting that Boaz's path was already cleared by a preexisting exclusion of Ruth from the biblical prohibition. While the Ketubbot passage has Boaz solving this problem himself by means of scriptural exegesis, the Yevamot passage might imply that the biblical prohibition was not addressed until it became politically relevant generations later.

My analysis assumes that no such exegesis of the biblical verse existed at the time of the book of Ruth - or rather that the book does not imagine that Boaz is working with such an understanding of the biblical law. The purpose of this brief look at the Bavli passages is simply to suggest that even rabbinic texts that advocate this limited understanding of the Torah's prohibition entertain the possibility that Boaz acted without the benefit of this understanding. It is worth noting that B. Makkot 23b portrays Boaz as someone who independently establishes a new practice - greeting one's fellow with the divine name - that is only subsequently affirmed by the heavenly beit din.

64. This possibility is suggested by Walfish, "Ha-hipus," 10. 
competing understandings of the biblical word, in this case of God's call to return. Elisha focuses on the verse from Jeremiah and understands the call to God's "children" to exclude himself, while R. Meir will later offer a reinterpretation of a verse from Psalms that issues the same call-shuvu — that is directed to all human beings ${ }^{65}$ and, according to R. Meir's derashah, invites all human beings to return.

I think it is most plausible to take Elisha's report at face value, to understand the words that exclude Elisha as indeed having issued from a heavenly voice. The story offers no indication that Elisha's report is not accurate; on the contrary, R. Meir's challenge to God in the episode in which he enacts the passage from Ruth implies that he accepts the fact that God has excluded Elisha. ${ }^{66}$ The proposal that the aggadah is crafted in relation to the book of Ruth offers additional support for the conclusion that God has excluded Elisha, as Ruth herself is implicated in the permanent exclusion of the Moabites that is scripturally mandated. Nonetheless, in the aggadah, as in the book of Ruth, the divine word that excludes is simply not addressed. In both stories, the protagonists go about their work of incorporating the outsider, of redeeming the one whom God has excluded, without ever justifying this in relation to the divine word that has placed this person irrevocably outside of the bounds of the community.

In order to address this puzzling feature of the two stories, I want to return to the earlier discussion of hesed and goodness and take it one step further. In the book of Ruth, I suggested, the redemption of Ruth is an expression of the quality of hesed that the characters attribute to God and that they praise when it is expressed in human action. Hesed entails going beyond the boundaries of what is required. Ruth's accompaniment of Naomi and providing for her needs goes beyond what is required, and so does Boaz's care of Ruth when she comes to glean in his field. In the background of this book are several biblical laws, relating to allowing poor people to gather in one's field, to the redemption of land, and to the widow of a man who has died without children. The relationship between the events of Ruth and these biblical laws is not always entirely clear. ${ }^{67}$ But it is clear, especially in the case of the first of these laws, that Boaz goes beyond what the law requires: he invites Ruth to drink from the water that his workers draw, he protects her from the young men working in his field, he includes her in his and the workers' meal, and he makes sure that she has extra produce from which to glean $(2: 9,14-16)$.

65. Rubenstein notes as a possibility that R. Meir sees the verse's address to "mortals" as including "all mortals."

66. While this does not necessarily mean that this is the narrator's stance, it does seem to strengthen that likelihood. R. Meir's challenge to God, after all, loses much of its force if God never actually declared Elisha to be excluded. And, in any event, the fact that R. Meir appears to accept Elisha's report is the crucial point-if he believes that God has indeed excluded Elisha, then how can he violate God's declaration that Elisha cannot return?

67. For a summary and brief discussion, see Zakovitch, 20-24. Bush, Ruth, 221-27, analyzes the law of levirate marriage in relation to the marriage of Ruth and Boaz. He concludes that Boaz was not legally obligated to marry Ruth; rather, Boaz fulfills a moral responsibility that goes beyond the requirements of the law, in the service of the core purposes that inform the law. 


\section{Devora Steinmetz}

I suggest that this same quality of hesed, in the sense of going beyond the boundaries of the law, explains the incorporation of Ruth into the community despite the law that forbids it. It is not just that Boaz's commitment to hesed convinces him that he must extend himself to the woman who has extended herself in hesed to others. It is that hesed, by its nature, cannot be bound by law. In most cases in the book, that unboundedness means that characters extend themselves beyond the law, acting in ways that fulfill the purposes of the law but that exceed what the law requires. But perhaps, in the case of the law forbidding a Moabite to enter the community, hesed means going beyond the bounds of the law in a different sense: breaking the bounds of the law. Boaz enacts the divine quality of hesed by doing what, from a legal perspective, is a violation of the rule that the law sets out. ${ }^{68}$

It is such a reading of the nature and role of hesed in the book of Ruth, I believe, that lies behind the aggadah. If Elisha's report of the heavenly voice is accurate, then R. Meir must be seen as speaking and acting in ways that violate the divine word that declared Elisha to be outside of the possibility of return. In the opening scene of the second act, R. Meir repeats the question that he had

68. This discussion has focused on how Ruth is incorporated into the community in light of the prohibition in Deuteronomy 23:4, but it is worth looking briefly as well at why she is worthy of being incorporated into the community. The Torah links the prohibition against Moabites and Ammonites entering the community to the behavior of these peoples while the Israelites were on their way (ba-derekh) from their exile in Egypt: they did not bring the Israelites bread (or food) and water, and they hired Balaam to curse them (Deuteronomy 23:5). Ruth, though, accompanies Naomi on her way to the land (va-derekh-1:7) and, once they arrive, takes it upon herself to gather food to bring home to Naomi. Responding to Ruth's actions, Boaz sees to it that she has bread (2:14) and water (2:9), and Ruth is able to share remnants of her meal with Naomi (2:18). Ruth's behavior is the antithesis of the behavior for which the Moabites are condemned: she reaches out to the person who is journeying toward the land, and she works to sustain her with food. Her actions evoke Boaz's reciprocal acts of sustenance with food and water, acts that enable Ruth to go further in supporting her mother-in-law.

Further, the Deuteronomy passage includes the theme of curse and blessing: while the Moabites and Ammonites attempted to have the Israelites cursed, God turned the curse into a blessing (Deuteronomy 23:6). In conclusion, the passage insists that one should not seek their peace nor their good (tovatam) forever. As I have noted, both blessing and goodness are important themes in the book of Ruth, and Ruth herself evokes and generates blessing in response to her goodness (3:10, 4:14-15).

Moving beyond the Deuteronomy passage, as many commentators have pointed out, Ruth's choice to leave birthplace and family and come to the land echoes the actions of Abraham and Rebecca. Note, in particular, the similarity between Ruth 2:11 and Genesis 12:1 (for discussion, see Zakovitch, Ruth, 76), and Ruth's commitment to go ('elekh, 1:16) in relation to Rebecca's commitment to go ('elekh, Genesis 24:58). See Zakovitch, pp. 28-29, for parallels and contrasts between the stories of Ruth and Rebecca.

The description of Ruth's behavior as antithetical to that of the Moabites might suggest that the law excluding Moabites should not apply to her, while the portrayal of Ruth as a spiritual descendant of Abraham and Rebecca might make it impossible to imagine excluding her from the community. It may well be that these two factors are sufficient, from the perspective of the book, to enable Ruth's incorporation into the community. Nevertheless, from a more formalistic legal perspective, the inclusion of Ruth still appears to be a violation of the biblical law. And so the question that I am pursuing in looking at our aggadah in the context of the book of Ruth is not why Ruth should be included, but how the reader can understand her inclusion in the face of an explicit biblical prohibition that would exclude her. 
put to Elisha in the final scene of the first act: "Will you not return/repent?" It was in response to the first time that R. Meir asked this question that Elisha explained that return is impossible for him, and it was then that Elisha disclosed to R. Meir the message of the heavenly voice that excluded Elisha from the invitation to return. Yet now, after asking this same question, R. Meir offers precisely the opposite message. He asserts that the invitation to return-shuvu - is extended to everyone, even to Elisha. And, in the following scene, R. Meir challenges God to redeem Elisha and declares that he will do so himself if God refuses. Both at Elisha's deathbed and at Elisha's grave, in word and in action, R. Meir refuses to accept the divine refusal to allow Elisha to return.

Now, it is true that R. Meir's conclusions about the possibility of return and about the imperative of redemption are based on biblical verses and his derashot on these verses. In that sense, then, his actions are justified. But it also true that R. Meir does not attempt to reread the words of the heavenly message that exclude Elisha. Those words are left hanging in the background of the story as R. Meir goes about the reincorporation of Elisha in the second act of the narrative. Like Boaz in the book of Ruth, then, R. Meir does what he understands is necessary without justifying his actions in relation to the divine word that they appear to violate. Like Boaz enacting the quality of divine hesed, R. Meir needs to enact the quality of divine goodness, and that is what he does. Tov 'Adonai la-kolthe conviction of God's unlimited goodness - simply trumps even God's own word that would exclude someone from that goodness.

$$
* * * * *
$$

This study has argued that the aggadah's account of R. Meir speaking, interpreting, and enacting a verse spoken by Boaz in the book of Ruth calls the reader to engage with the broader narrative of Ruth and to imagine in what ways the book of Ruth might be present in the aggadah. ${ }^{69}$ Several observations have emerged from the contrapuntal reading of these two stories that I have undertaken in response to this invitation.

First, reading the two stories in relation to each other helps highlight core themes of the aggadah as well as of the book of Ruth. For example, exploring parallels between the two stories brings into focus the theme of accompaniment in the aggadah, and in particular the powerful image of two individuals walking together in a space between boundaries that one or the other cannot cross. Conversely, the aggadah's concern with the notion of goodness and the conviction that the end can be better than the beginning helps call attention to the significance of the word tov in the book of Ruth and the theme of reversal toward good that shapes that book.

69. For the notion of the presence of a text in another text, see the formulation of Steve Moyise in his discussion of intertextuality in biblical studies: “... a text cannot be studied in isolation. It belongs to a web of texts which are (partially) present whenever it is read or studied." "Intertextuality and the Study of the Old Testament in the New Testament," in The Old Testament in the New Testament: Essays in Honour of J. L. North, ed. Steve Moyise, JSNT Supplement Series 189 (Sheffield: Sheffield Academic Press, 2000), 14-41 (the quotation is on pp. 15-16). 


\section{Devora Steinmetz}

In addition, reading the two stories in relation to each other can help the reader interpret puzzling elements in one or both of the stories. Thus, an analysis of the role of hesed and the interplay of human and divine action in the book of Ruth helps clarify how each of the stories would have its readers understand the characters' commitment to incorporating the outsider. In the book of Ruth, the mechanism of inclusion is the belief that God is a life-giving source of goodness and hesed and that it is the task of human beings to enact those divine qualities. It is this same hermeneutic of goodness, anchored in biblical verses, that enables R. Meir to interpret the divine word in a way that ensures a good outcome, and to enact that very outcome. And the relationship between law and hesed in the book of Ruth suggests a possible way to understand R. Meir's choice to incorporate Elisha into the community in opposition to the divine word.

The starting point of this investigation was the observation that the climax of the aggadah takes the form of an enactment and interpretation of a biblical verse. What has emerged over the course of the ensuing exploration is that the entire aggadah is in a sense a reenactment and interpretation of the book in which that verse appears. These two observations help bring into focus a point discussed earlier in this study: that the aggadah tells a story that speaks powerfully about how a person might read Torah and how a person might live out his or her understanding of Torah.

Devora Steinmetz

Drisha Institute 